\title{
Analyses of Four Inceptisols of Holocene Age, East-Central Alabama
}

\section{U.S. GEOLOGICAL SURVEY BULLETIN 1589-C}

Prepared in Cooperation with the U.S. Department of Agriculture, Soil Conservation Service

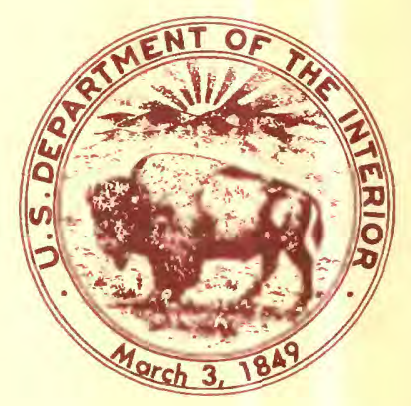




\section{AVAILABILITY OF BOOKS AND MAPS OF THE U.S. GEOLOGICAL SURVEY}

Instructions on ordering publications of the U.S. Geological Survey, along with prices of the last offerings, are given in the current-year issues of the monthly catalog "New Publications of the U.S. Geological Survey." Prices of available U.S. Geological Survey publications released prior to the current year are listed in the most recent annual "Price and Availability List." Publications that are listed in various U.S. Geological Survey catalogs (see back inside cover) but not listed in the most recent annual "Price and Availability List" are no longer available.

Prices of reports released to the open files are given in the listing "U.S. Geological Survey Open-File Reports," updated monthly, which is for sale in microfiche from the U.S. Geological Survey, Books and Open-File Reports Section, Federal Center, Box 25425, Denver, CO 80225. Reports released through the NTIS may be obtained by writing to the National Technical Information Service, U.S. Department of Commerce, Springfield, VA 22161; please include NTIS report number with inquiry.

Order U.S. Geological Survey publications by mail or over the counter from the offices given below.

\section{BY MAIL}

\section{Books}

Professional Papers, Bulletins, Water-Supply Papers, Techniques of Water-Resources Investigations, Circulars, publications of general interest (such as leaflets, pamphlets, booklets), single copies of Earthquakes \& Volcanoes, Preliminary Determination of Epicenters, and some miscellaneous reports, including some of the foregoing series that have gone out of print at the Superintendent of Documents, are obtainable by mail from

\section{U.S. Geological Survey, Books and Open-File Reports Federal Center, Box 25425 Denver, CO 80225}

Subscriptions to periodicals (Earthquakes \& Volcanoes and Preliminary Determination of Epicenters) can be obtained ONLY from the

\section{Superintendent of Documents \\ Government Printing Ofrice \\ Washington, D.C. 20402} ments.)

(Check or money order must be payable to Superintendent of Docu-

\section{Maps}

For maps, address mail orders to

\section{U.S. Geological Survey, Map Distribution Federal Center, Box 25286 \\ Denver, CO 80225}

Residents of Alaska may order maps from

\author{
Alaska Distribution Section, U.S. Geological Survey, \\ New Federal Bullding - Box 12 \\ 101 Twelfth Ave., Fairbanks, AK 99701
}

\section{OVER THE COUNTER}

\section{Books}

Books of the U.S. Geological Survey are available over the counter at the following Geological Survey Public Inquiries Offices, all of which are authorized agents of the Superintendent of Documents:

- WASHINGTON, D.C.--Main Interior Bldg., 2600 corridor, 18 th and C Sts., NW.

- DENVER, Colorado--Federal Bldg., Rm. 169, 1961 Stout St.

- LOS ANGELES, California--Federal Bldg., Rm. 7638, 300 N. Los Angeles St.

- MENLO PARK, California--Bldg. 3 (Stop 533), Rm. 3128, 345 Middlefield Rd.

- RESTON, Virginia--503 National Center, Rm. 1C402, 12201 Sunrise Valley Dr.

- SALT LAKE CITY, Utah--Federal Bldg., Rm. 8105, 125 South State St.

- SAN FRANCISCO, Californla--Customhouse, Rm. 504, 555 Battery St.

- SPOKANE, Washington-U.S. Courthouse, Rm. 678, West 920 Riverside Ave..

- ANCHORAGE, Alaska--Rm. 101, 4230 University Dr.

- ANCHORAGE, Alaska--Federal Bldg, Rm. E-146, 701 C St.

\section{Maps}

Maps may be purchased over the counter at the U.S. Geological Survey offices where books are sold (all addresses in above list) and at the following Geological Survey offices:

- ROLLA, Missouri--1400 Independence Rd.

- DENVER, Colorado--Map Distribution, Bldg. 810, Federal Center

- FAIRBANKS, Alaska--New Federal Bldg., 101 Twelfth Ave. 


\title{
Analyses of Four Inceptisols of Holocene Age, East-Central Alabama
}

\author{
By H.W. MARKEWICH, W.C. LYNN, M.J. PAVICH, \\ R.G. JOHNSON, and J.C. MEETZ
}

Prepared in Cooperation with the U.S. Department of Agriculture, Soil Conservation Service

Detailed analyses of soils developed in Holocene-age alluvium of the lowest terrace along Uphapee Creek and the Tallapoosa River in east-central Alabama 


\title{
DEPARTMENT OF THE INTERIOR DONALD PAUL HODEL, Secretary
}

\author{
U.S. GEOLOGICAL SURVEY \\ Dallas L. Peck, Director
}

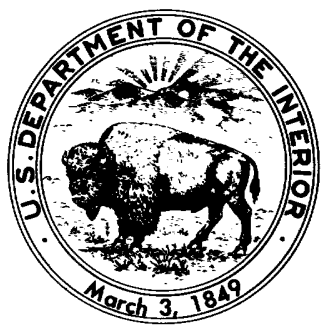

Any use of trade names and trade marks

in this publication is for descriptive

purposes only and does not constitute

endorsement by the U.S. Geological Survey

For sale by the

Books and Open-File Reports Section

U.S. Geological Survey

Federal Center, Box 25425

Denver, CO 80225

Library of Congress Cataloging in Publication Data

Analyses of four inceptisols of Holocene age, east-central Alabama.

(Pedologic studies in the eastern United States, relations to geology; ch. C) (U.S.

Geological Survey bulletin ; 1589-C)

Bibliography: $p$.

"Prepared in cooperation with the U.S. Department of Agriculture, Soil Conservation Service."

Supt. of Docs. no.: | 19.3:1589-C

1. Inceptisols-Alabama-Composition. 2. Soils-Alabama-Composition. 3.

Soil formation-Alabama. 4. Alluvium-Alabama. 5. Geology, Strati-

graphic-Holocene. 6. Geology-Alabama. I. Markewich, Helaine W.

II. United States. Soil Conservation Service. III. Series. IV. Series: U.S.

Geological Survey bulletin ; $1589-\mathrm{C}$.

QE75.B9 no. 1589-C 557.3 s [631.4] $88-600330$

[S599.A4] 


\section{PREFACE}

Some geologic investigations of Quaternary deposits, especially in the conterminous United States, have attempted to use relative degrees of weathering and soil formation to establish chronosequences of glacial and (or) fluvial landforms. Most studies have been in the glacial terrane of the midcontinent and the Western United States. Few such studies have been conducted in the Eastern United States, especially in the unglaciated Middle Atlantic and Southeastern States.

From 1979 to 1984 , the U.S. Geological Survey and the U.S. Department of Agriculture's Soil Conservation Service conducted cooperative regional studies of the relations between soils and geology in the Middle Atlantic and Southeastern States. The primary goal of the studies was to determine if soil properties could be used to estimate ages of associated landforms. Coral, wood fragments, and peat were sampled from constructional landforms of fluvial and marine origin in order to estimate ages by isotopic analyses; these ages were then related to regional biostratigraphic and lithostratigraphic correlations. Specific site investigations were conducted on Pliocene to Holocene marine and fluvial terraces in the Atlantic and eastern Gulf Coastal Plains and the Appalachian Piedmont. Soils on granite, schist, and quartzite parent rocks of the Appalachian Piedmont were sampled to test the use of soil properties as indicators of soil age. Each chapter of this bulletin series examines the relation of soils to geology in a specific geographic area.

The cooperative study involved research scientists from both agencies and field personnel from State offices of the Soil Conservation Service. Responsibility for sample analysis was divided between the Department of Agricultures's National Soil Survey Laboratory in Lincoln. Nebr., and the U.S. Geological Survey in Reston, Va. This report was prepared by scientists from both agencies who participated in specific site investigations or in studies of pedogenic processes. 


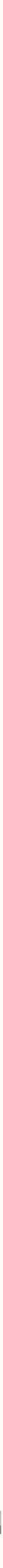




\section{CONTENTS}

\section{Preface III}

\section{Abstract C1}

Introduction C1

Classification of soils $\mathbf{C 1}$

Geologic setting $\mathbf{C 3}$

Field and laboratory methods $\mathbf{C 4}$

Acknowledgments $\mathbf{C 4}$

\section{Results C4}

Data presentation $\mathbf{C 4}$

Physical properties $\mathbf{C 4}$

Depositional characteristics of alluvium $\quad \mathbf{C 4}$

Effects of pedogenic processes $\mathbf{C 6}$

Mineralogy C6

Optical mineralogy of very fine sand fraction C6

Mineralogy of the clay-sized fraction $\mathbf{C 6}$

Chemical properties $\mathbf{C 8}$

Effects of parent material composition and geographic position $\quad$ C8

Bulk chemical analyses C9

Discussion C9

Clay mineralogy C9

Alteration of clay mineralogy by chemical processes $\mathbf{C 1 0}$

Stratigraphy versus pedogenesis $\mathbf{C 1 2}$

Conclusions $\mathbf{C 1 3}$

References cited C13

Tables 1-7 C15

\section{FIGURES}

1. Map showing location of study areas and study sites along Uphapee

Creek and the Tallapoosa River in east-central Alabama C2

2. Schematic diagram of the stratigraphic relations between terrace

alluvium, a lens of carbonaceous clay and sand and leaf material, and the underlying sands and clays of the Cretaceous Tuscaloosa Group C4

3. Plot of the percentages of $<2-\mu \mathrm{m}$ fraction of the four study pedons C5

4-7. X-ray diffraction patterns for:
4. Pedon S81AL-087-001 C7
5. Pedon S81AL-087-002 C7
6. Pedon S81AL-101-001 C8
7. Pedon S81AL-101-002 C9

8. Graphs showing weight percentages of:

A. $\mathrm{Fe}_{2} \mathrm{O}_{3}, \mathrm{Al}_{2} \mathrm{O}_{3}$, and $\mathrm{SiO}_{2}$ plotted by depth for each horizon of each pedon $\mathbf{C 1 0}$

B. $\mathrm{SiO}_{2}$ and zircon plotted against depth for each horizon of each pedon C11

\section{TABLES}

1. Analytical methods and units of expression for analyses conducted at

Soil Conservation Service National Soil Laboratory C16

2. Pedon S81AL-087-001:
A. Field description $\mathbf{C 1 7}$
$B$. Textural analysis $\mathbf{C 1 7}$
C. Physical and chemical analyses $\mathbf{C 1 8}$
$D$. Optical mineralogy of very fine sand fraction of selected horizons $\mathbf{C 1 9}$
E. Bulk chemistry C19 
3. Pedon S81AL-087-002:
A. Field description
B. Textural analysis $\mathbf{C 2 0}$
C. Physical and chemical analyses $\mathbf{C 2 1}$
D. Optical mineralogy of very fine sand fraction of selected horizons C22
E. Bulk chemistry $\mathbf{C 2 2}$

4. Pedon S81AL-101-001:
A. Field description $\mathbf{C 2 3}$
B. Textural analysis $\mathbf{C 2 3}$
C. Physical and chemical analyses $\mathbf{C 2 4}$
$D$. Optical mineralogy of very fine sand fraction of selected horizons $\mathbf{C 2 5}$
E. Bulk chemistry $\mathbf{C 2 5}$

5. Pedon S81AL-101-002:
A. Field description $\mathbf{C 2 6}$
B. Textural analysis $\mathbf{C 2 6}$
C. Physical and chemical analyses $\mathbf{C 2 7}$
$D$. Optical mineralogy of very fine sand fraction of selected horizons $\mathbf{C 2 8}$
E. Bulk chemistry $\mathbf{C 2 8}$

6. Intervals of maximum clay accumulation versus intervals of translocated clay C29

7. Particle-size distribution of sand on a clay-free base for each pedon $\mathbf{C 2 9}$ 


\title{
Analyses of Four Inceptisols of Holocene Age, East-Central Alabama
}

\author{
By H.W. Markewich,, ${ }^{1}$ W.C. Lynn, ${ }^{2}$ M.J. Pavich, ${ }^{3}$ R.G. Johnson, ${ }^{3}$ and J.C. Meetz ${ }^{4}$
}

\begin{abstract}
Four soils developing in terrace alluvium of Uphapee Creek and the Tallapoosa River in east-central Alabama were described, sampled, and analyzed. The ${ }^{14} \mathrm{C}$ ages of the alluvium are between 5,000 and 7,500 years. Field classifications of the four pedons ranged from Dystrochrepts to Hapludults, but textural, mineralogical, and chemical analyses indicate that all four pedons should be classified as Fluventic Dystrochrepts. Data indicate that there has been minimal chemical and (or) mineralogical alteration of the alluvium. All of the pedons have significant clay content, but only two pedons show evidence for clay movement and in situ alteration of clay minerals. The best evidence for clay films is found in one of the two pedons that do not have argillic horizons. Different interpretations of field and laboratory data raise questions about textural classification of argillic horizons.
\end{abstract}

Soils developed in the terrace alluvium of Uphapee Creek are more smectitic than those developed in the alluvium of the Tallapoosa River terraces. All the soils are predominantly kaolinitic. Differences in clay mineralogy reflect differences in provenance between the two drainage basins.

The low $\mathrm{pH}$ and high aluminum saturation values for the two pedons developed in Uphapee Creek alluvium appear to be directly related to (1) the lignitic and pyritiferous composition of the Cretaceous sands and clays into which the channel of Uphapee Creek is cut, (2) the shallow subsurface flow of water from the Cretaceous sediment into the terrace alluvium, and (3) the frequent flooding of the terraces caused by the infiltration of flood water through the alluvium.

\section{INTRODUCTION}

Data obtained from investigations into the rates of soil formation are the foundation of soil chronosequence studies. Determining the rates of the chemical reactions and physical alterations involved in soil formation (pedogenesis) is necessary before absolute ages, based on the degree of development, can be assigned to individual soils. It has been suggested that the rates of chemical and

\footnotetext{
IU.S. Geological Survey, Doraville, GA 30360.

${ }^{2}$ U.S. Department of Agriculture, Soil Conservation Service. National Soil Survey Laboratory, Lincoln. NE 68508-3866.

${ }^{3}$ U.S. Geological Survey, Reston, VA 22092.

${ }^{4}$ U.S. Department of Agriculture, Soil Conservation Service,
} Auburn. AL 36830. physical soil-forming processes decrease, or become asymptotic, through time (Nikiforoff, 1949; Birkeland, 1984). Although some studies have suggested that this hypothesis is not completely correct, there appears to be agreement that initial weathering and soil-forming rates are rapid and decrease through time (Birkeland, 1984). This report presents data from detailed chemical and physical analyses of Holocene age soils developed on terraces of Uphapee Creek and the Tallapoosa River in east-central Alabama. The data show that, for soils developed in 5,000- to 7,500-year-old alluvium in eastcentral Alabama, many of the chemical processes involved in weathering are related to the physical environment of the terrace and to the mineralogy of the parent material. Although these chemical processes have little effect on horizonization, they do influence cation exchange capacity and base saturation of the soils. Some physical characteristics of soils, such as clay films, can persist through erosion and subsequent redeposition to become indigenous short-term characteristics of the new parent material. (This phenomenon is particularly common in overbank deposits.) Textural characteristics of the parent material, such as fining-upward depositional sequences, are dominant over the pedogenic textural characteristics (horizonization) of the soil

\section{Classification of Soils}

Many of the soils developing in the Piedmont and Coastal Plain of Alabama are in the Ultisol soil order (Soil Survey Staff, 1975). Ultisols are found in middle to low latitudes in areas where, in some seasons, precipitation is greater than evapotranspiration. Water is thus allowed to move through the solum into the underlying parent material. In Ultisols, leaching removes bases from sola at the same rate or at a rate more rapid than that at which bases are released from sola by weathering. Most bases are held in surface vegetation and in the upper few centimeters of sola. Common clay minerals include kaolinite and hydroxyinterlayered vermiculite. Halloysite and gibbsite are also present in small amounts. Clay-sized quartz, goethite, hematite, and muscovite are common. Argillic horizons of Ultisols commonly have base saturation values (by sum of the cations) of less than 35 percent.

Inceptisols are present on flood plains and on the lowermost terraces of many Coastal Plain drainages and 

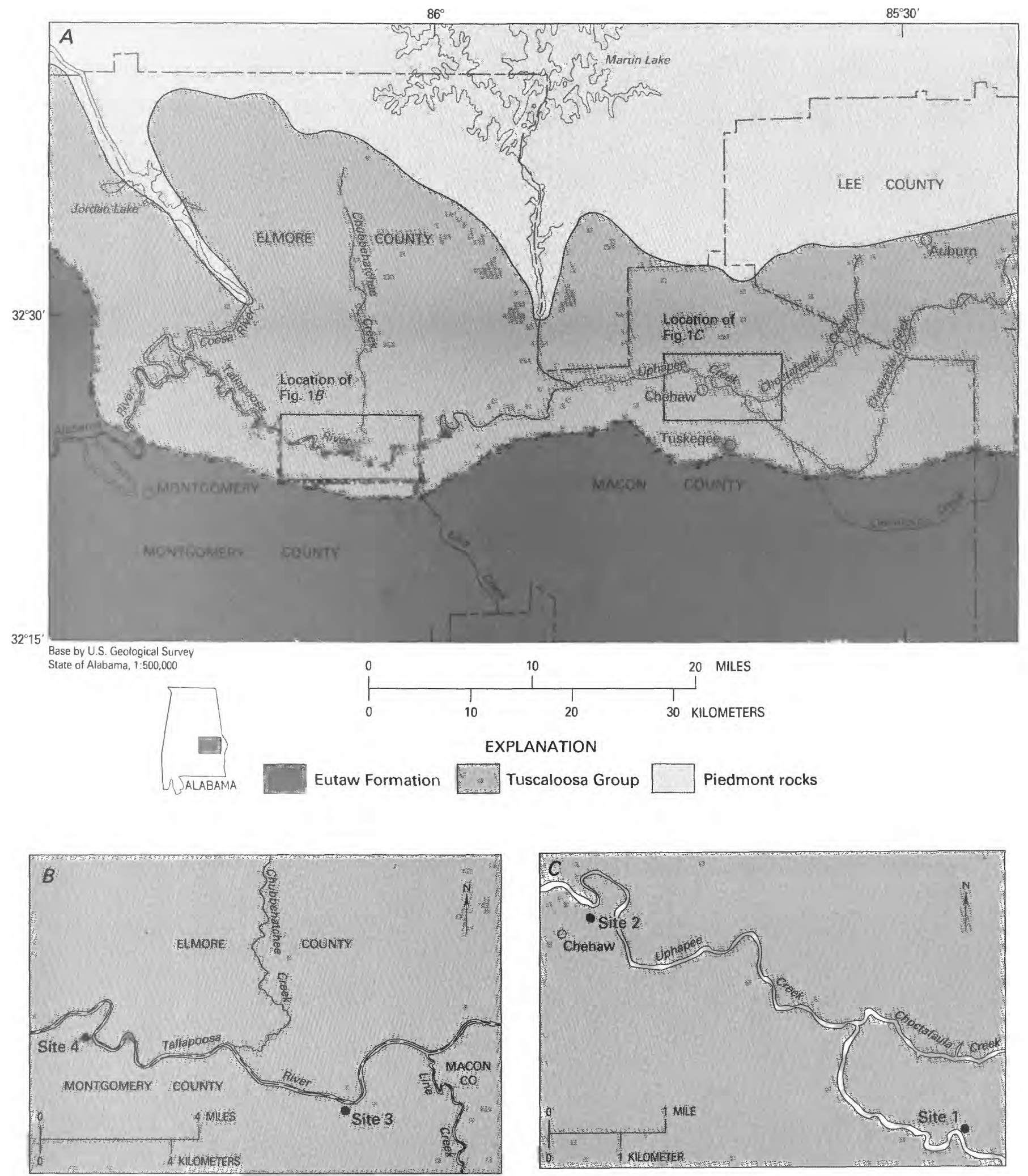

Figure 1. Location of study areas and study sites along Uphapee Creek and the Tallapoosa River in east-central Alabama. Patterns designate the main geologic units of the region. Map scales are given for the detailed maps of each study area. 
are commonly associated with the Udult suborder of Ultisols (Soil Survey Staff, 1975). The base saturation values of Inceptisols are generally greater than those of Ultisols. Their percentage of weatherable (labile) minerals may be greater, and (or) their horizonization may be less well developed. Clay mineralogy is generally similar in the two soil types.

On the basis of field descriptions, two of the soils described in this study were assigned to the Udult suborder of Ultisols, and two soils were assigned to the Dystrochrept suborder of Inceptisols. Each soil described has physical characteristics attributable to both parent material and pedogenic processes. Reevaluation of the field data, in combination with microfabric studies and laboratory analyses, indicates that all four soils should be classified as Fluventic Dystrochrepts.

\section{Geologic Setting}

The Tallapoosa River drains the Coastal Plain of Alabama and the Piedmont of Alabama and Georgia. Uphapee Creek, a major tributary of the Tallapoosa, joins the river in the upper Coastal Plain of east-central Alabama $25 \mathrm{~km}$ south of the boundary between the Piedmont and the Coastal Plain (fig. 1). Like the Tallapoosa River, Uphapee Creek drains both Piedmont and Coastal Plain terranes, but Uphapee Creek is predominantly a Coastal Plain drainage, incised into the nonmarine Upper Cretaceous Tuscaloosa Group (Markewich and Christopher, 1982b). Palynological data indicate a Tuscaloosa age (early Late Cretaceous) for the sediments exposed in the channel of Uphapee Creek east of Chehaw, Ala. The sediments are characterized by petrified and lignitic wood fragments, which are commonly associated with crystalline pyrite. Uphapee Creek west of Chehaw and the Tallapoosa River downstream of its junction with Uphapee Creek are incised into a stratigraphically younger sandy unit $30 \mathrm{~m}$ thick that was mapped as part of the Tuscaloosa Group by Markewich and Christopher (1982b). No palynological data were available for these strata, which only locally contain small amounts of pyrite-rich lignitic material. Marine sands and clays of the Upper Cretaceous Eutaw Formation (Markewich and Christopher, 1982b) stratigraphically overlie strata of the Tuscaloosa Group, crop out along the northward flowing tributaries of Uphapee Creek and the Tallapoosa River, and cap the interstream divides south of these two streams (fig. 1).

The four pedons sampled for this study are from the terrace directly adjacent to Uphapee Creek and the Tallapoosa River (fig. 1). This terrace, the dominant geomorphic feature of both valleys, is continuous for 64 $\mathrm{km}$. The degree of modification of the terrace surface increases downstream, and radiocarbon ages from wood at the base of the alluvium suggest the possibility of two depositional periods. The ${ }^{14} \mathrm{C}$ ages of $5,260 \pm 90$ and $5,470 \pm 100$ yr B.P. for the terrace at sites 3 and 4 (Markewich and Christopher, 1982a) appear to be from a part of the terrace that has been extensively modified by flooding, or else they represent the age of a terrace that is inset into the main terrace. The main terrace has radiocarbon ages of $6,360 \pm 110$ and $7,520 \pm 110 \mathrm{yr}$ B.P. (Markewich and Christopher, 1982a). Because it is difficult to geomorphically separate the two surfaces and because the difference between the maximum age of the younger surface and the minimum age of the older is less than 1,000 years, the two surfaces are considered as one terrace for this report. ${ }^{5}$

Alluvium associated with the main terrace is dominantly a fining-upward sequence of pebble- to cobblesized gravel to medium- to fine-grained sand and silt. The sand- to cobble-sized fraction of the alluvium is dominantly quartz and contains a small percentage of rock fragments. The silt fraction is predominantly quartz. The terrace alluvium varies in thickness from 2 to $7 \mathrm{~m}$ and commonly has an abrupt lower contact with the underlying sediments of Cretaceous age. At each locality, the dated material was collected from carbonaceous lenses near the alluviumCretaceous contact. A diagrammatic sketch in figure 2 shows the relation between the terrace alluvium, a lens of carbonaceous clay and leaf material, and the Cretaceous sands and clays near site 2 . The stratigraphic relations presented in figure 2 are representative of the relations at each of the sample localities.

Locally, younger sediments are cut into the main terrace. Wood from meander-bend deposits that cut into the terrace near site 1 yielded a ${ }^{14} \mathrm{C}$ age of $250 \pm 70 \mathrm{yr}$ B.P. Clay balls in alluvium of the main terrace near site 1 contain fragments of wood of Pleistocene age; one fragment, tentatively identified as juniper, yielded a ${ }^{14} \mathrm{C}$ age of $27,000 \pm 520$ yr B.P. (Markewich and Christopher, 1982a).

Both the microfossil and macrofossil data indicate that Holocene deposition has been under humid subtropical climatic conditions similar to those found in the area today (Shipp, 1985). The flora has been dominated by pine and

\footnotetext{
5 Specific definitions of the terms "flood plain" and "terrace" vary with the perspective of the user (for example, geomorphologist, pedologist. or engineer) and with the objective of the study. Linsley and others ( 1975 , p. 428) defined the flood plain of a river as "the valley floor adjacent to the incised channel, which may be inundated during high water." The term "terrace" has generally been used to mean an aggradational form, or a thin accumulation of unconsolidated material on a beveled surface, contained within a valley and composed of unconsolidated material that is found along the border and above a stream or river. A terrace is generally considered to mark a former water level or flood plain. Both Uphapee Creek and the Tallapoosa River periodically fill their respective channels and flood onto their flood plains and (or) the adjacent terrace. Flood intervals can be as often as twice a year or as infrequent as once in 5 years. Thin layers of silty sand, present as irregular patches on those parts of the terrace within several tens of meters of the stream channels. appear to be the result of periodic floods, but flooding causes no other apparent modification to the surface morphology of the terrace.
} 


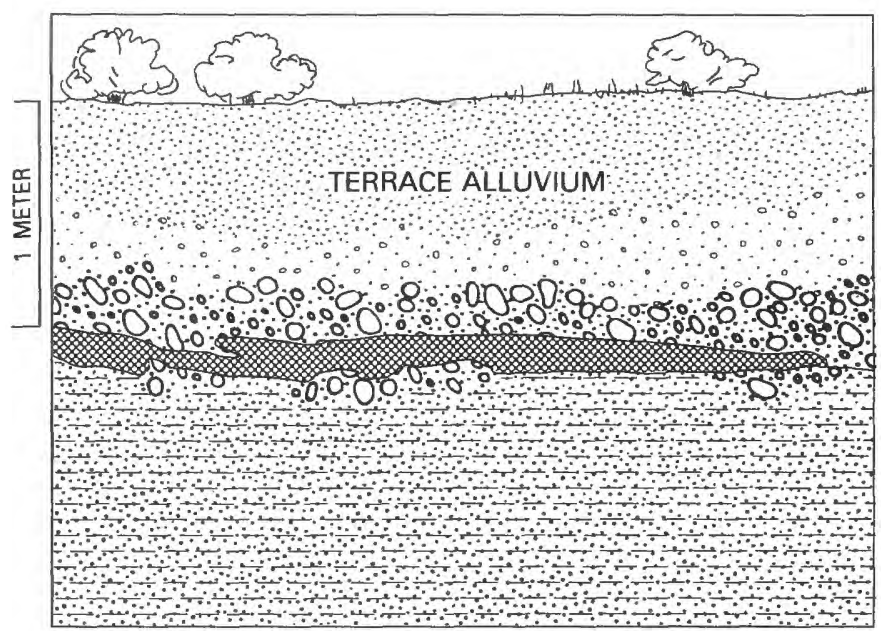

Figure 2. Stratigraphic relations between terrace alluvium (a fining-upward sequence), a lens of carbonaceous clay and sand and leaf material, and the underlying sands and clays of the Cretaceous Tuscaloosa Group (bottom unit).

oak forest, along with shrubs, herbs, and aquatic plants (Markewich and Christopher, 1982a; Shipp, 1985).

\section{Field and Laboratory Methods}

For the purpose of this report, the pedons sampled are considered to be developed in alluvium of the lowest terrace; all sites are within $26 \mathrm{~m}$ laterally of the stream channel. The level of water in the stream channel controls in part the water table in terrace alluvium and influences the agricultural use of the terrace.

The four study pedons were described and sampled by the authors and local personnel from the U.S. Department of Agriculture's Soil Conservation Service (SCS). Pedon numbers are standard SCS notation, which gives the year, the State abbreviation, the county number, and the pedon number in the county (for example, S81 AL-087001). Pedons discussed in this report are referred to by the last six digits of their complete pedon numbers. Horizon designations follow the revision of the Soil Survey Manual (Soil Survey Staff, 1981) and also a brochure produced by Cornell University and the Department of Agriculture's Agency for International Development (Soil Survey Staff, 1986). New horizon designations are used in the text of this report; both old and new designations are given in the illustrations and tables. Samples were sent to the SCS National Soil Survey Laboratory (NSSL) in Lincoln, Nebr., where they were split; one set was then sent to the U.S. Geological Survey (USGS) laboratories in Reston, Va., and the other was retained by the NSSL. Samples were analyzed for standard physical and chemical characteristics at the NSSL. Some of the analyses conducted at the NSSL are particle-size distribution, cation exchange capacity, $\mathrm{pH}$, base saturation, and $\mathrm{X}$-ray diffraction on the $<2-\mu \mathrm{m}$ fraction of selected horizons (magnesium saturated at room temperature, magnesium saturated and glycerol solvated at room temperature, potassium saturated at 300 and $500^{\circ} \mathrm{C}$ ). Diffraction patterns presented in this report represent glass-mounted slides of clay that were magnesium saturated at room temperature. The USGS laboratories conducted additional analyses, including bulk chemistry by X-ray fluorescence and analyses of iron and aluminum by oxalate extraction and by atomic absorption.

\section{Acknowledgments}

We would like to express our appreciation to J.P. Owens, R.B. Mixon, and J.T. Hack of the U.S. Geological Survey and R.B. Daniels and Klaus Flach of the Soil Conservation Service for their initiative in suggesting a cooperative project between the two agencies and for their encouragement throughout the study period. We also extend our thanks for the assistance of Soil Conservation Service field personnel in sampling the study profiles. Cleo Stubbs, Wade Hurt, H.R. Finney, and James Brown helped to select the field sites and describe the pedons.

\section{RESULTS}

\section{Data Presentation}

Exact descriptions of the soil and weathering profiles at each site are given in tables $2 A 3 A, 4 A$, and $5 A$. Analytical results for samples from the profiles are presented in tables $2 B-E, 3 B-E, 4 B-E$, and $5 B-E$. Table 6 shows evidence for translocation of clay by pedogenic processes as opposed to depositional clay for each profile, and table 7 presents particle-size distribution data on a clay-free basis. Site 1 is the farthest upstream along Uphapee Creek. Site 4 is located approximately $48 \mathrm{~km}$ downstream from the junction of Uphapee Creek and the Tallapoosa River (see fig. 1). Figure 3 is a graphic presentation of the study pedons that shows the weight percentage of the $<2-\mu \mathrm{m}$ fraction for each profile, plotted by horizon. X-ray diffraction patterns of the $<2-\mu \mathrm{m}$ fraction are presented in figures 4 through 7 . Figure $8 \mathrm{~A}$ shows variation with depth of $\mathrm{Fe}_{2} \mathrm{O}_{3}, \mathrm{Al}_{2} \mathrm{O}_{3}$, and $\mathrm{SiO}_{2}$ by weight percent. Figure $8 B$ shows variations with depth of zircon (in parts per million) in comparison with the weight percentage of $\mathrm{SiO}_{2}$.

\section{Physical Properties}

\section{Depositional Characteristics of Alluvium}

Textural data from all four pedons show that the soils are developing in fining-upward sequences of fluvial sands, silts, and clays. The original stratification is domi- 

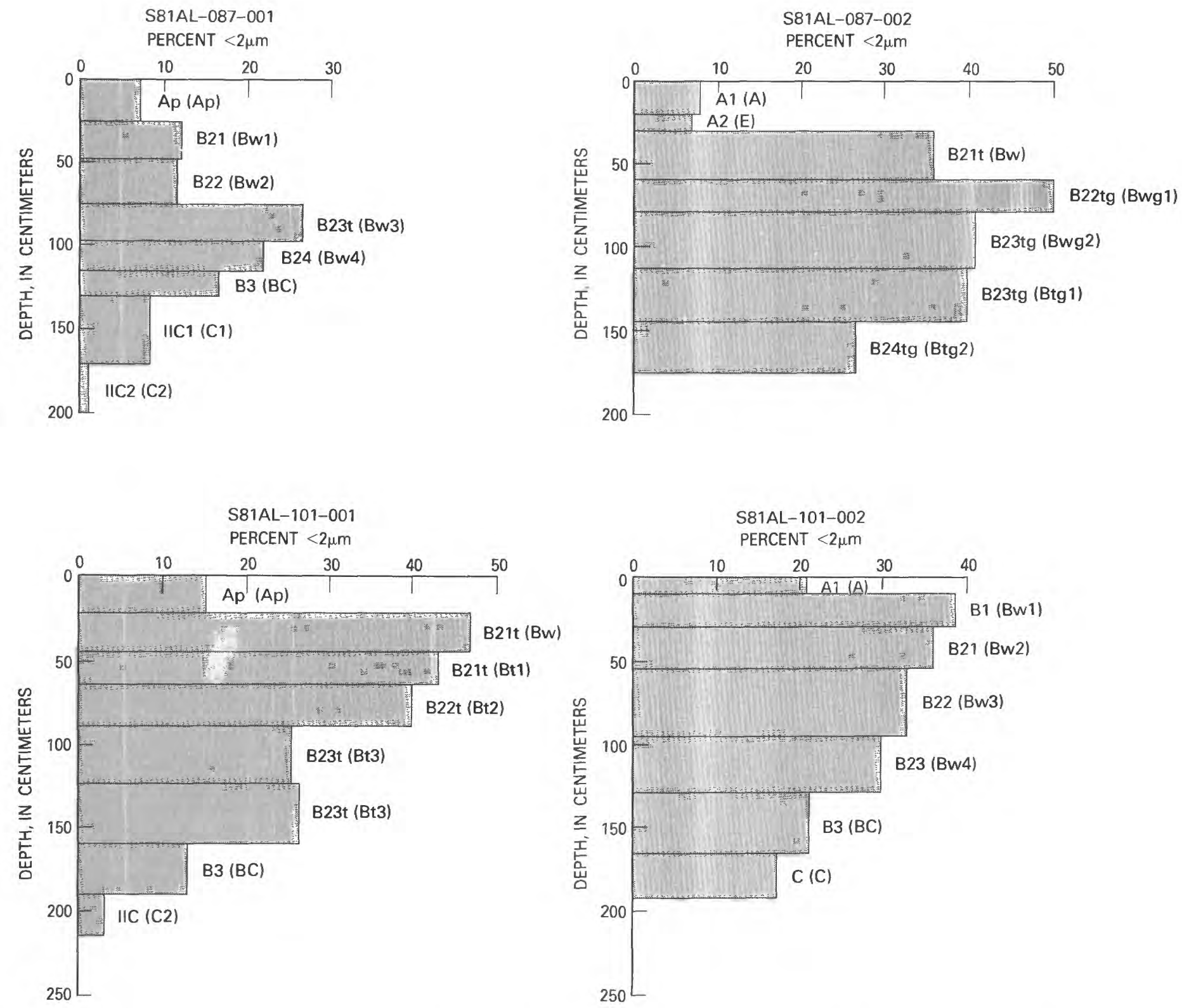

Figure 3. Weight percentages of $<2-\mu \mathrm{m}$ fraction of the four study pedons. Percentages given for composite samples from each horizon.

nant over pedogenic horizonization. Data in tanle $2 B$ show a threefold increase in the percentage of very fine sand toward the surface of pedon 087-001 and a correlative decrease in the coarser sand-sized fractions toward the surface. Data from pedon 087-002 (table 3B) show a decrease in the percentage of sand between 176 and 58 $\mathrm{cm}$ and an increase in silt-sized material above $176 \mathrm{~cm}$. Coarser size fractions show variable patterns of distribution. The percentages of very fine and fine sand in pedons 101-001 and 101-002 (tables $4 B, 5 B$ ) are variable with depth and appear to reflect variations in fluvial deposition; that is, particle- size data support stratification changes at $22,89,161$, and $190 \mathrm{~cm}$ at site 4 in pedon 101-001 (tables 6, 7). The percentage of silt in the upper $2 \mathrm{~m}$ ( $30-50$ percent) is much higher in terrace alluvium from pedons 101-001 and 101-002 (tables $4 B, 5 B$ ) along the Tallapoosa River than it is in terrace alluvium from Uphapee Creek (4-35 percent) (see tables $2 B, 3 B$ ). The percentage of clay varies from 1.2 to 50 percent. Clay maxima do not appear to be coincident with maxima of pedogenic development. In both pedons 101-001 and 101-002, clay maxima are reached within 30 $\mathrm{cm}$ of the surface, and the percentage of clay decreases downward from the clay maxima (fig. 3 , tables $4 B, 5 B$ ).

Preliminary horizon designations of pedon 087-001 placed a lithologic discontinuity at $73 \mathrm{~cm}$ (the top of the Bw3 horizon), where there is a significant change in the relative percentages of sand, silt, and clay (table $2 B$ ). We decided to omit the designations of lithologic change, since 
change in particle-size distribution is an indigenous characteristic of most alluvial sequences and does not imply a change in source material.

\section{Effects of Pedogenic Processes}

Pedons at sites 1 and 2 (087-001 and 087-002, respectively) show little to no evidence of clay movement. Pedon 087-001 has no clay films in any horizon and only a weak suggestion of clay bridging in the Bw4 horizon. Increases in clay at 26 and $73 \mathrm{~cm}$ are sufficient for argillic horizon designation, but these depths coincide with evidence for change in the particle size of the parent material (tables $2 B, 6,7$ ). Pedon 087-002 has clay increases sufficient for argillic horizon designation at 36 and $58 \mathrm{~cm}$ (table $3 B$ ), but these increases appear to be related to deposition rather than to pedogenic processes. In the Bw horizon, there are clay linings in some pores. The linings do not completely mask the sand and silt grains. A few reddish films on ped surfaces in the same horizon are also present in lower Bwg horizons of the same pedon.

Field designations suggested that pedon 101-001 at site 3 has a large enough clay increase at $22 \mathrm{~cm}$ for argillic designation (table $4 B$ ). The microfabric of pedon 101-001 suggests that the first evidence of moved clay is only in the lower part of the Bw horizons, beginning at $47 \mathrm{~cm}$. This pedon has thin reddish coatings on few faces and oriented clay in pores in all $\mathrm{Bt}$ horizons. The $\mathrm{Bt} 3$ horizon has some reddish and black films on ped faces. The black films are described as mottles in the pedon description (see table 4A). Pedon 101-002 has the strongest expression of moved clay of the four pedons. This fact is particularly interesting, since pedon 101-002 is classified as a Dystrochrept, and an argillic horizon was not described. Clay increase from the A horizon to the $\mathrm{Bw}$ horizon at $8 \mathrm{~cm}$ is sufficient for argillic designation, but there is also evidence for a change in the particle-size distribution of the parent material at this depth (tables 6, 7). Although no clay films were described, $\mathrm{MnO}_{2}$ cutans were prominent from Bw2 downward. Muscovite was evident throughout both pedons 101-001 and 101-002, but the total content was considered to be small (tables $4 D, 5 D$ ).

Pedon 101-002 has unusual distinct strong brown clay coatings ( 7.5 YR 5/6, dry) in the A horizon, which are unlike those found deeper in the pedon. These clay films are probably inherited from a soil that was eroded and redeposited as overbank sediments at this locality. This hypothesis raises the distinct possibility of intact alluvial transport of argillic fabric.

\section{Mineralogy}

\section{Optical Mineralogy of the Very Fine Sand Fraction}

The very fine sand fraction in each study pedon is $>70$ percent quartz. Potassium feldspar is the dominant weatherable mineral in these soils (tables $2 D, 3 D, 4 D, 5 D$ ). The percentage of potassium feldspar does not change significantly between the $\mathrm{C}$ and $\mathrm{B}$ horizons in any pedon. Pedons 087-001 and 087-002 in the Uphapee Creek drainage have less muscovite and higher potassium feldspar than do pedons 101-001 and 101-002 along the Tallapoosa River. The lack of difference in mineralogy between horizons in any one pedon suggests that the mineralogical differences are related to differences in parent material, possibly to differences in provenance between the Uphapee and Tallapoosa drainages. For further study, scanning electron microscope photographs and photomicrographs could be useful to show any surface alteration of feldspar grains

\section{Mineralogy of the Clay-Sized Fraction}

Pedon 087-001 contains roughly equal amounts of smectite and kaolinite, secondary amounts of quartz and muscovite, and a trace of gibbsite (fig. 4). This pedon is the most smectitic of the four profiles. The $\mathrm{C} 2$ horizon contains as much smectite as the superjacent horizons, an indication that the smectite is in the parent material. The broad 15-A peak from the magnesium-saturated sample expands to $17 \mathrm{~A}$ on glycerol solvation, and a small 10-A peak remains. Heating of a potassium-saturated sample to $350^{\circ} \mathrm{C}$ causes collapse to $10 \mathrm{~A}$ of most of the smectite. The $\mathrm{Bw} 3$ horizon contains a higher percentage of kaolinite and vermiculite relative to smectite than the $\mathrm{C} 2$ horizon does. The kaolinite peaks are sharp, suggesting well-crystallized kaolinite. The Bwl horizon contains about the same percentages of smectite, kaolinite, and vermiculite as the Bw3 horizon. The presence of a high percentage of smectite in an acidic soil $-\mathrm{pH}\left(\mathrm{H}_{2} \mathrm{O} 4.5\right.$ to $4.7, \mathrm{pH}(\mathrm{KCl}) 3.4$ to 3.9--suggests that the smectite is inherited and that there has been insufficient time for alteration. The upward increase in kaolinite and vermiculite (presumably aluminum hydroxyinterlayered) relative to smectite suggests some in situ alteration of smectite.

Pedon 087-002 contains much more kaolinite and muscovite relative to smectite than pedon 087-001 does. The $\mathrm{C}$ horizon of pedon 087-002 is kaolinitic (fig. 5). There is a strong smectite peak and a moderately strong muscovite peak in horizon $\mathrm{C}$. The Bwgl horizon is also kaolinitic. The percentage of smectite in the Bwgl horizon decreases relative to kaolinite and mica in comparison with that of the $\mathrm{C}$ horizon. This decrease may be due to mineral alteration and (or) clay translocation. The 14-A nonexpandable vermiculite peak is present, as the glycolated sample shows, but its percentage cannot be determined.

In pedon 101-001, the $\mathrm{C}$ horizon is predominantly kaolinitic and contains secondary amounts of vermiculite, smectite, and muscovite (fig. 6). Glycerol solvation of a magnesium-saturated sample reduces the intensity of the 14-A peak and thus indicates a randomly interstratified mixed layer assemblage of 2:1 layers. In the $\mathrm{Bt} 3$ horizon, 


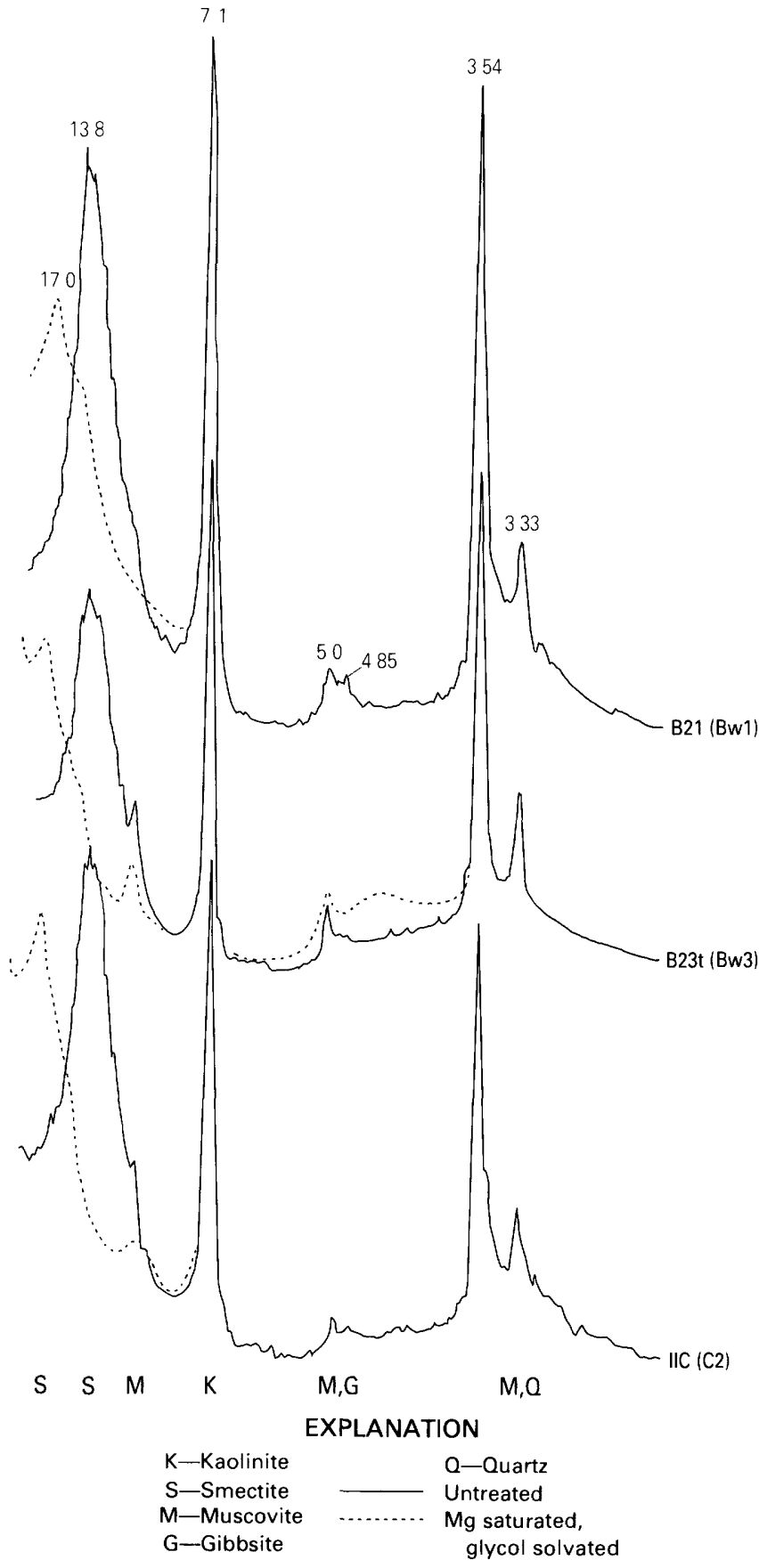

Figure 4. X-ray diffraction patterns of magnesium-saturated and glycerol-solvated (magnesium saturated) $<2-\mu$ m samples from pedon S81AL-087-001. Kaolinite and smectite are dominant. Glycerol solvation causes a shift of the smectite to a 17-A D-spacing. Gibbsite, quartz, and muscovite are also present in small amounts.

Figure 5. X-ray diffraction patterns of magnesium-saturated and glycerol-solvated (magnesium saturated) $<2-\mu$ m samples from pedon S81AL-087-002. Kaolinite and smectite are dominant. Glycerol solvation causes a shift of the smectite to a 17-A D-spacing. Muscovite and quartz are present in small amounts.
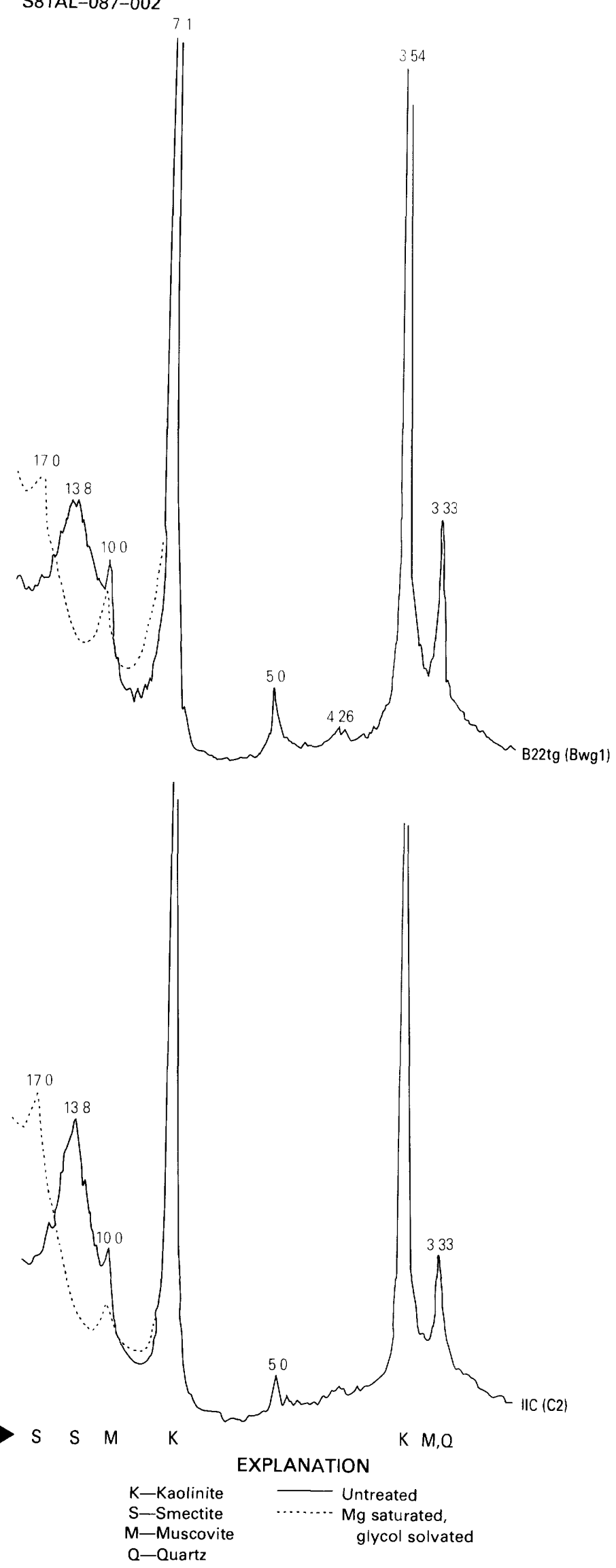
S81AL-101-001

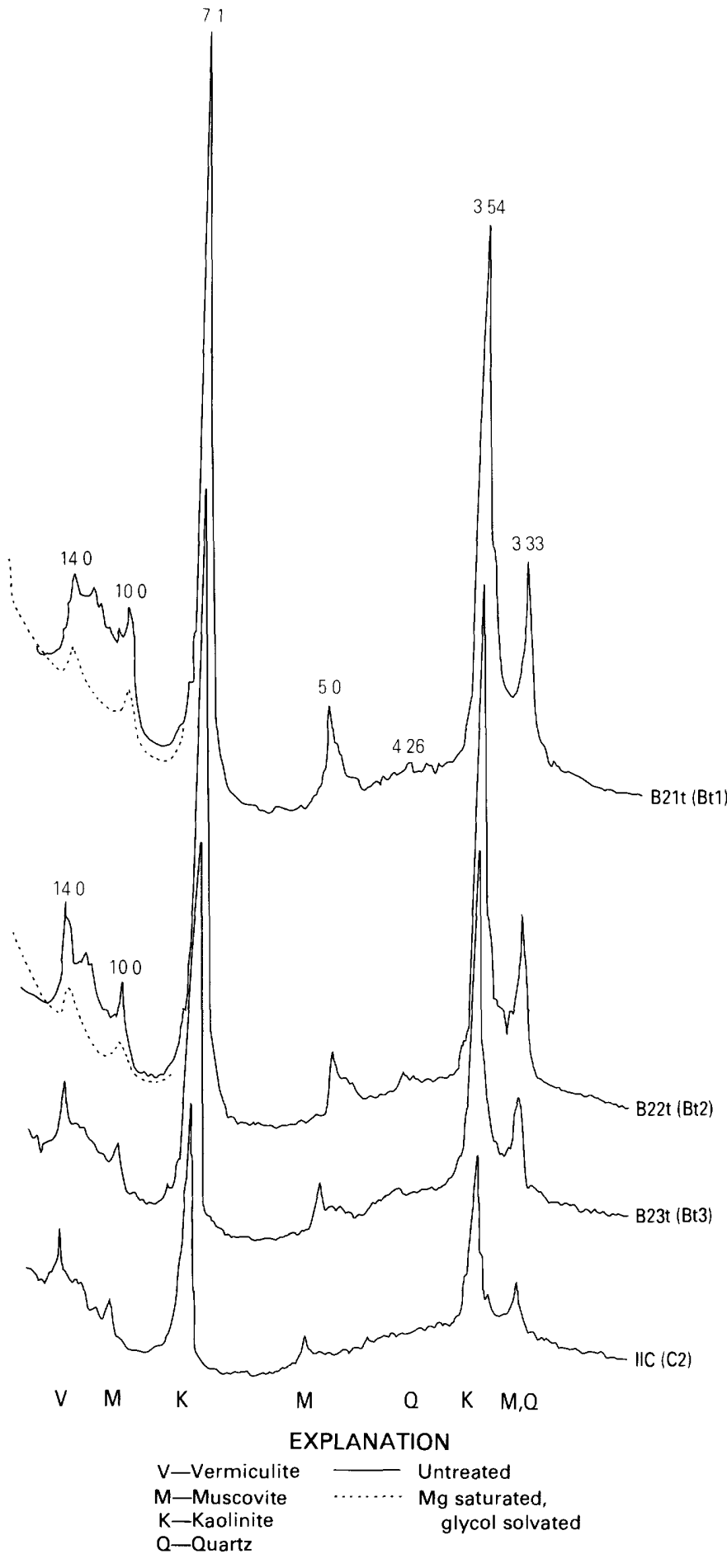

Figure 6. X-ray diffraction patterns of magnesium-saturated and glycerol-solvated (magnesium saturated) $<2-\mu$ m samples from pedon S81AL-101-001. Kaolinite is dominant throughout the profile. Vermiculite, muscovite, and quartz are present in small amounts. In the untreated pattern for the Bt1 horizon, a distinct peak occurs at $13.8 \mathrm{~A}$. On glycerol solvation, no distinct peak appears at a higher D-spacing. The high background between 13.8 and $17 \mathrm{~A}$ suggests the presence of a small amount of smectite. the kaolinite is dominant, and the 10- and 14-A peaks are more distinct than they are in the $\mathrm{C}$ horizon. Both the 10and 14-A peaks remain with glycerol solvation. In the $\mathrm{Bt} l$ and $\mathrm{Bt} 2$ horizons, there are slight increases in the $10-$ to 14-A region of the mixed layer relative to the same interval in the $\mathrm{Bt} 3$ horizon, but all phases are less abundant than kaolinite.

X-ray diffraction patterns from samples of pedon 101-002 are presented in figure 7. The pedon is predominantly kaolinitic and contains lesser amounts of smectite, vermiculite, and muscovite. There is little change in peak intensities between the $\mathrm{C}$ horizon and the Bw3 horizon. The Bw3 does show slightly greater intensity of the vermiculite peak.

For all four pedons, differential thermal analysis confirms the presence of kaolinite and corroborates the interpretation of X-ray diffraction patterns, which indicated that kaolinite is dominant at sites 2, 3, and 4 (pedons 087-002, 101-001, and 101-002).

\section{Chemical Properties}

\section{Effects of Parent Material Composition and Geographic Position}

Chemical data (tables $2 C, 3 C, 4 C, 5 C$ ) indicate that all pedons contain appreciable organic carbon $>0.2$ percent), have low bases, are acidic, and have aluminum extractable by $\mathrm{KCl}$. Sites in Uphapee Creek (pedons 087 001 and 087-002) have somewhat lower base saturation and more $\mathrm{KCl}$-extractable aluminum and are more acidic than sites along the Tallapoosa River (pedons 10I-001 and 101-002). The lowest $\mathrm{pH}$ values of pedons 087-001 and 087-002 are associated with the 60- to 100-percent values for aluminum saturation and correspondingly low extractable bases to depths of $2 \mathrm{~m}$ (tables $2 C, 3 C$ ). Extractable bases and $\mathrm{pH}$ values are significantly higher and aluminum saturation values are significantly lower in pedons 101-001 and 101-002 than they are in pedons 087-001 and 087-002.

Pedons 087-001 and 087-002 are developed in Uphapee Creek terrace alluvium, which overlies lignitic and pyrite-rich sands and clays of the Upper Cretaceous Tuscaloosa Group. The Tuscaloosa Group as mapped by Markewich and Christopher (1982b) also forms the valley walls of Uphapee Creek. Repeated flooding of alluvium by water that has been derived from and (or) has flowed through the pyrite-rich parent material greatly affects the acidity of the alluvium and the bulk chemistry of the sediment. The parent material may also affect the organic carbon content of the soils. The pedons exhibit irregular decreases in organic carbon with depth and relatively high $(>0.2$ percent) values of organic carbon to depths of 150 $\mathrm{cm}$ or more. 

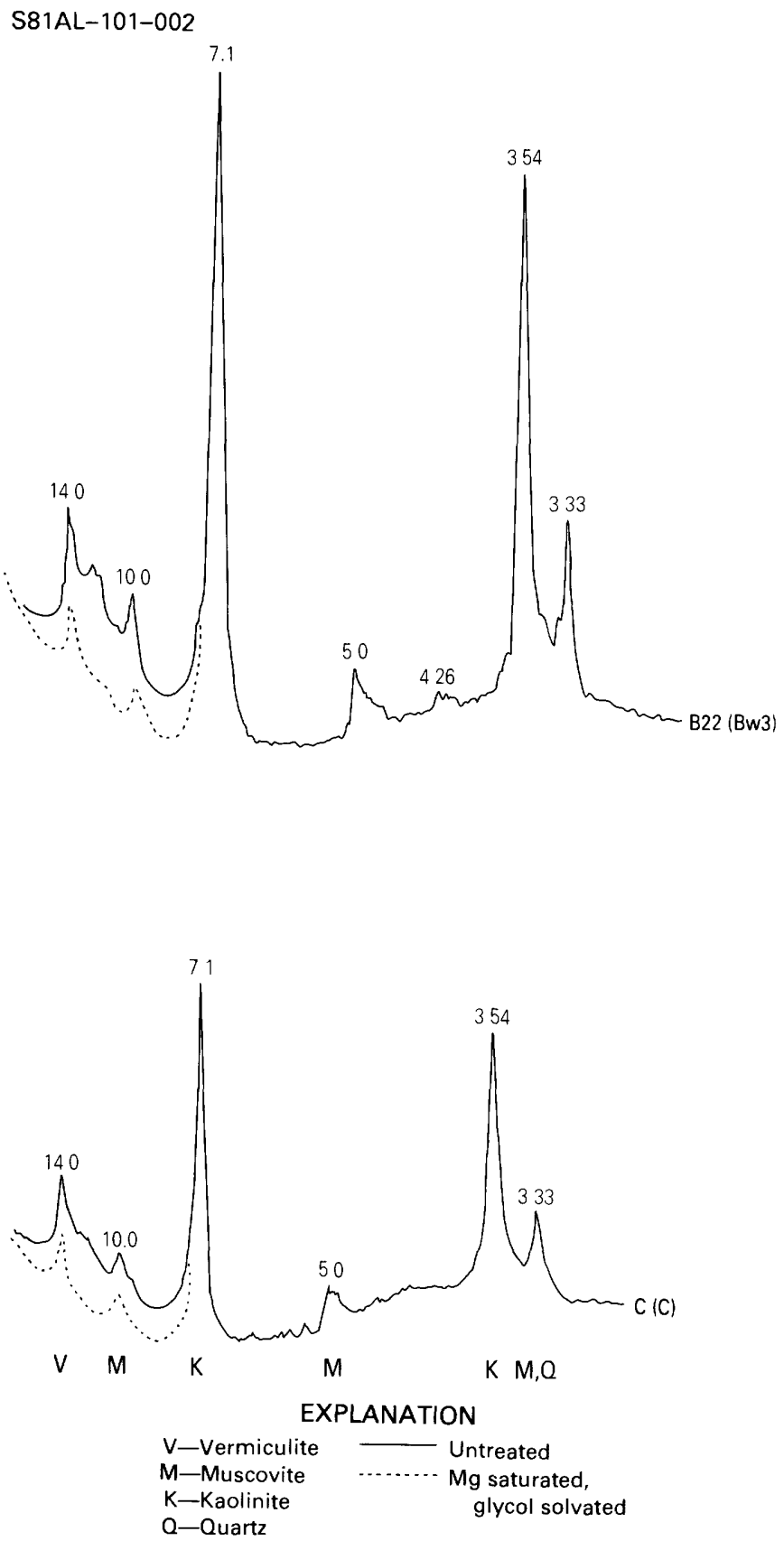

Figure 7. X-ray diffraction patterns of magnesium-saturated and glycerol-solvated (magnesium saturated) $<2-\mu$ m samples from pedon S81AL-101-002 have essentially the same pattern as those from pedon 101-001. Kaolinite is dominant throughout the profile. Vermiculite, muscovite, quartz, and possibly smectite are present in small amounts.

\section{Bulk Chemical Analyses}

Some results of bulk chemical analyses are plotted in figures $8 A$ and $8 B$ (data for each pedon are given in tables $2 E, 3 E, 4 E, 5 E$ ). Figure $8 A$ shows, for each of the four pedons, the weight percentages of $\mathrm{SiO}_{2}, \mathrm{Al}_{2} \mathrm{O}_{3}$, and $\mathrm{Fe}_{2} \mathrm{O}_{3}$ for each horizon versus depth. Figure $8 B$ shows the weight percentages of $\mathrm{SiO}_{2}$ and $\mathrm{Zr}$ (in parts per million) for each horizon versus depth. The distribution patterns of the major elements show that $\mathrm{SiO}_{2}$ decreases and $\mathrm{Al}_{2} \mathrm{O}_{3}$ increases are correlative with the amount of clay in the horizon.

In pedon 087-001, the departures from relatively constant weight percentages take place in the clay-rich $\mathrm{Bw} 3$ and $\mathrm{Bw} 4$ horizons. $\mathrm{Fe}_{2} \mathrm{O}_{3}$ shows little variation in comparison with $\mathrm{Al}_{2} \mathrm{O}_{3}$ and $\mathrm{SiO}_{2}$. In pedon 087-002, the high percentage of kaolinite in the $\mathrm{Bw}$ and $\mathrm{Bt}$ horizons is reflected by high $\mathrm{Al}_{2} \mathrm{O}_{3}$ and low $\mathrm{SiO}_{2}$ percentages below a depth of $30 \mathrm{~cm}$. The decrease of $\mathrm{Al}_{2} \mathrm{O}_{3}$ and the increase of $\mathrm{SiO}_{2}$ with depth correspond to the decreasing percentage of clay with depth. In pedon 101-001, $\mathrm{SiO}_{2}$ and $\mathrm{Al}_{2} \mathrm{O}_{3}$ also reflect the percentage of clay. The relatively small variation of $\mathrm{Fe}_{2} \mathrm{O}_{3}$ suggests that clay distribution rather than pedogenic removal of $\mathrm{SiO}_{2}$ is responsible for the $\mathrm{Al}_{2} \mathrm{O}_{3}$ distribution. The patterns in pedon 101-002 are similar to those in pedon 101-001.

Zirconium values (expressed as parts per million) have been used as an index of chemical alteration because zirconium is one of the least mobile elements during weathering (Sudom and Arnaud, 1971; Harden, 1987). Zirconium data from the four pedons plotted on figure $8 B$ show that zirconium is covariant with $\mathrm{SiO}_{2}$. This covariance indicates relatively little movement of $\mathrm{SiO}_{2}$ relative to zirconium and suggests that chemical alteration of the original parent material has been minimal. These data agree with the mineralogical data from the four study pedons and with the hypothesis of minimal pedogenic alteration of the parent material in these sola.

\section{DISCUSSION}

\section{Clay Mineralogy}

The amount of smectite in Uphapee Creek alluvium is significantly greater than that in Tallapoosa River alluvium, owing to the difference in the source areas of the sediments. Uphapee Creek is receiving fine-grained sediments from the Upper Cretaceous nonmarine Tuscaloosa Group and the marine Eutaw Formation. Residual soils on the Tuscaloosa Group in adjacent Lee County, studied by Karathanasis and Hajek (1983), have a montmorillonite mineralogy, as do many of the soils developed on the Eutaw Formation. The Tallapoosa drainage, by contrast, contains sediments from the more kaolinite-rich regolith (saprolite) developed on the crystalline rocks of the Piedmont. The difference in source areas accounts for the much higher kaolinite content and the lower smectite content of soils at sites 3 and 4 (pedons 101-00l and I01-002). 

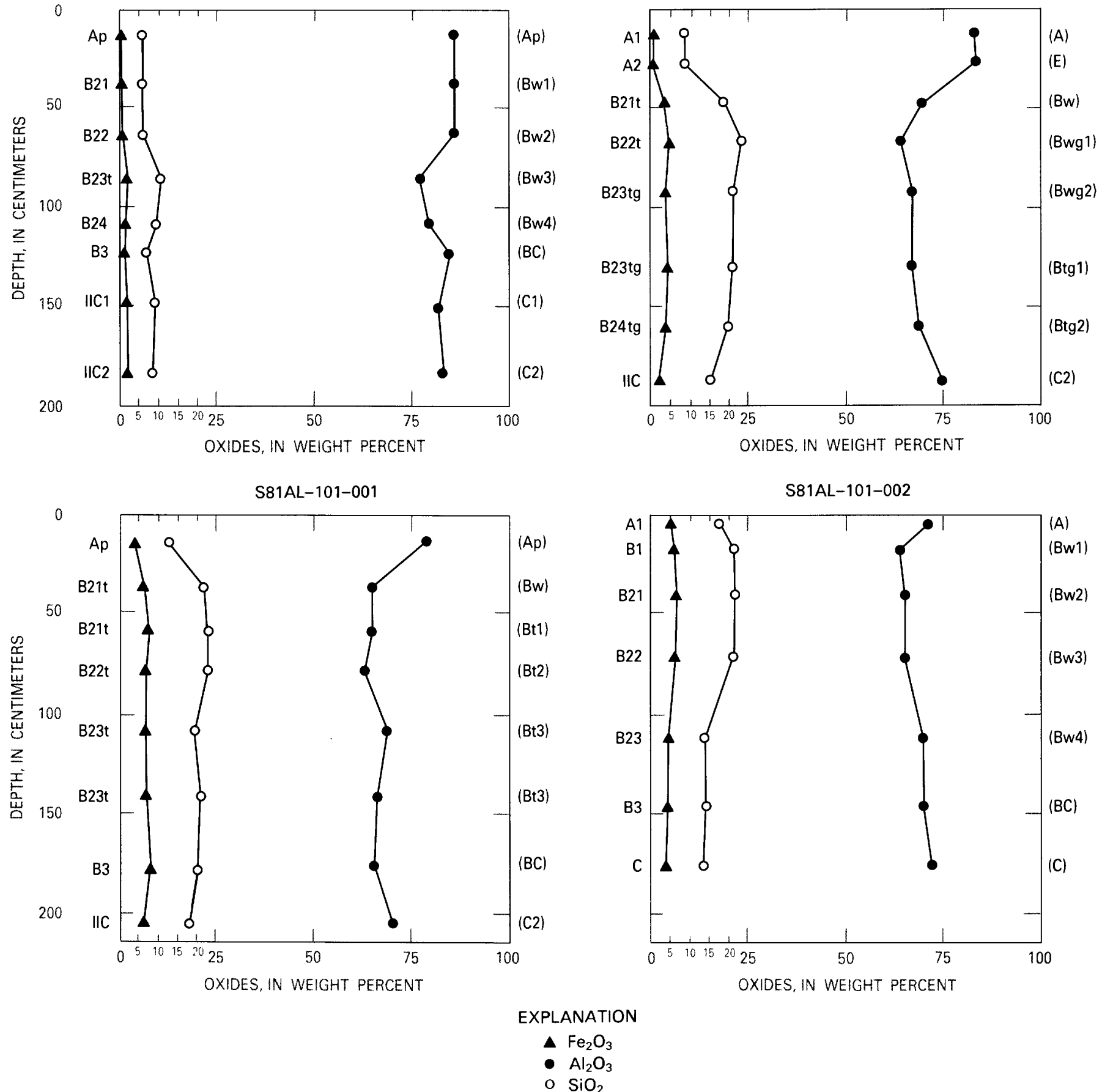

Figure $8 \mathrm{~A}$. Weight percentages of $\mathrm{Fe}_{2} \mathrm{O}_{3}, \mathrm{Al}_{2} \mathrm{O}_{3}$, and $\mathrm{SiO}_{2}$ plotted by depth for each horizon of the four study pedons.

\section{Alteration of Clay Mineralogy by Chemical Processes}

Neither the X-ray diffraction patterns nor the bulk chemical data show much evidence for chemical alteration of minerals in the parent material. Overall, the chemical analyses from these profiles support the interpretation that the percentage of clay determines the bulk chemistry. The distribution of the clay, generally increasing toward the surface, and the clay mineralogy support the interpretation that the clay is depositional rather than pedogenic. The lack of chemical alteration is reflected in the relative constancy of the $\mathrm{Fe}_{2} \mathrm{O}_{3}$ values. If $\mathrm{SiO}_{2}$ loss were responsible for the $\mathrm{Al}_{2} \mathrm{O}_{3}$ increases in the $\mathrm{Bt}$ horizons, then $\mathrm{Fe}_{2} \mathrm{O}_{3}$ would increase with $\mathrm{Al}_{2} \mathrm{O}_{3}$.

The lack of alteration in potassium feldspar and 
$\mathrm{SiO}_{2}$, IN WEIGHT PERCENT

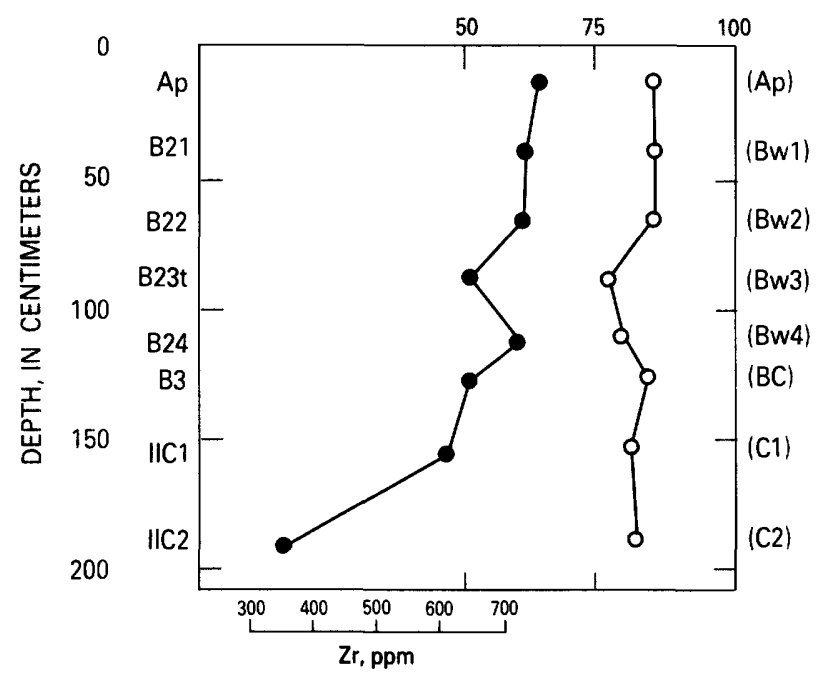

S81AL-101-001

$\mathrm{SiO}_{2}$, IN WEIGHT PERCENT

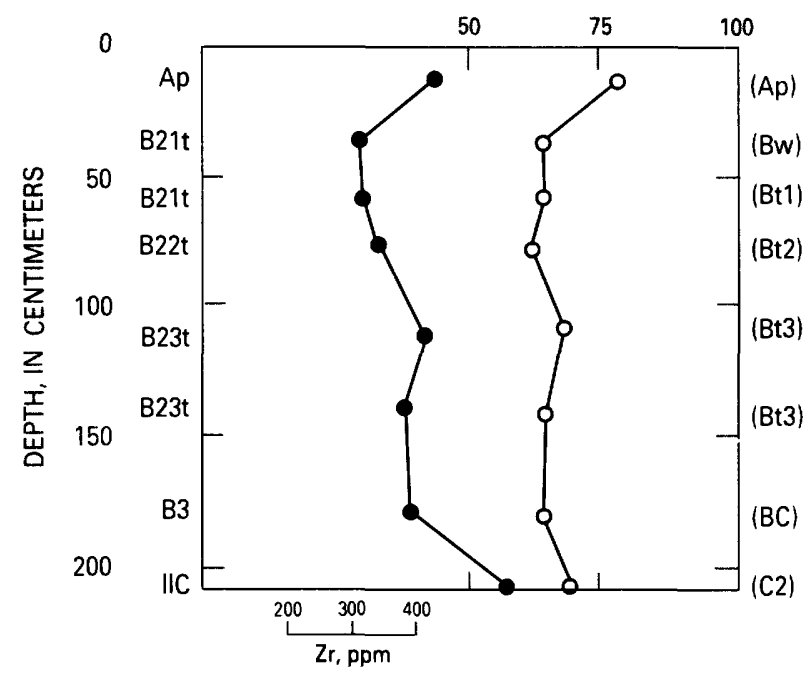

$\mathrm{SiO}_{2}$, IN WEIGHT PERCENT

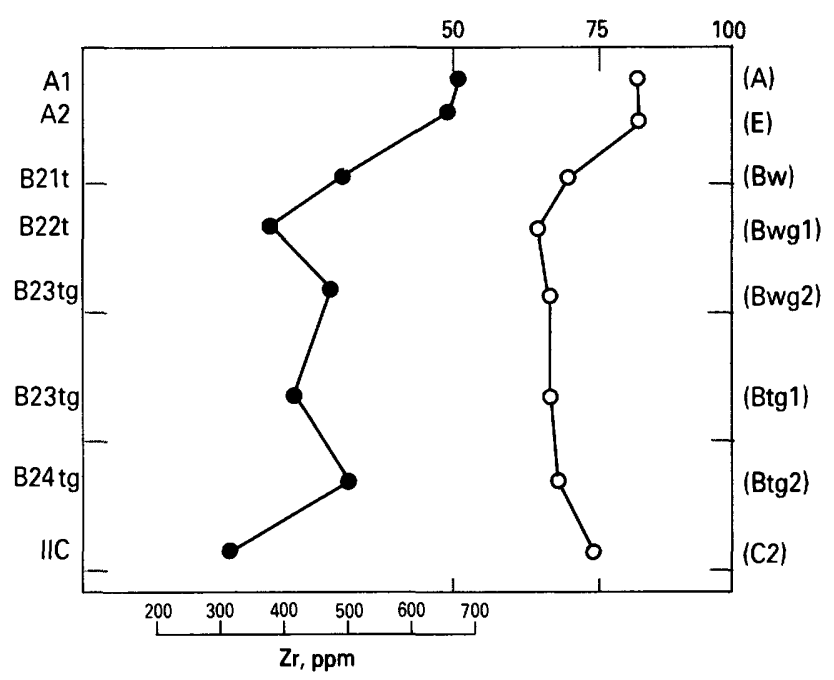

S81AL-101-002

$\mathrm{SiO}_{2}$, IN WEIGHT PERCENT

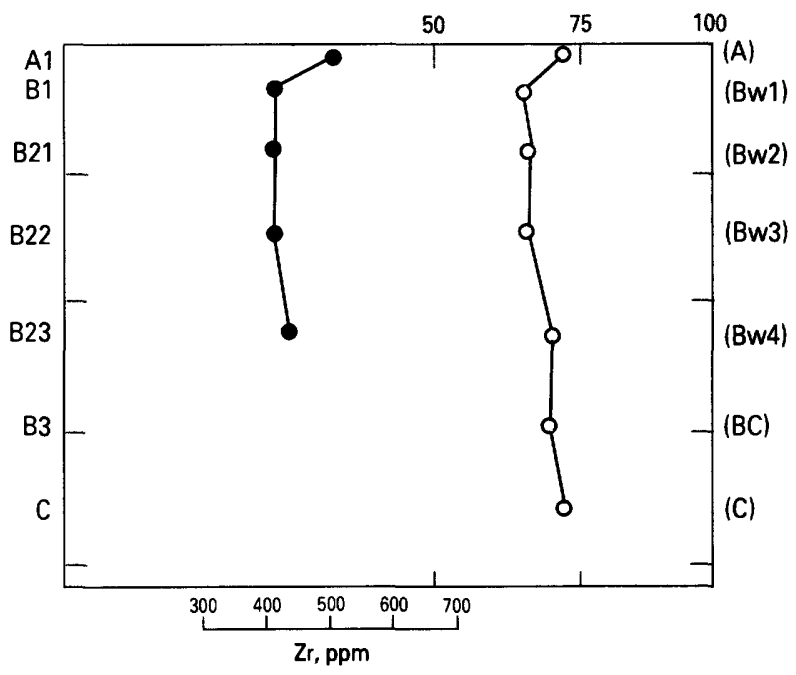

EXPLANATION

- $\mathrm{SiO}_{2}$

- $\mathrm{Zr}$

Figure $8 \mathrm{~B} . \mathrm{SiO}_{2}$ (in weight percent) and $\mathrm{Zr}$ (in parts per million) plotted against depth for each horizon of each study pedon.

muscovite, the most abundant "weatherable parent minerals," in less than 10,000 years is not surprising, given the slow kinetics. The lack of alteration of smectitic clay is, however, unexpected. In soils of the Southeastern United States and in areas of significant rainfall and volcanic soils, smectite may alter in only a few thousand years (Altschuler and others, 1963; Karathanasis and Hajek, 1983). X-ray diffraction patterns of the $<2-\mu \mathrm{m}$ fraction show that mineral alteration has been slight. The lack of alteration may be the result of the young Holocene age(s) of the parent material and (or) of chemical conditions that enhance the stability of the clay phases originally present. Smectite stability in low pH pedons may be the result of high dissolved silica activities (Karathanasis, 1982). Concentrations of dissolved elements were not measured at these localities, so we cannot comment on dissolved components. Chemical data, however, indicate that there is no substantial loss of $\mathrm{SiO}_{2}$ from these profiles.

As a test of this hypothesis, we can consider the amount of clay in each pedon. The total amount of clay formed and removed from eluvial horizons should provide an assessment of soil development (if eluvial horizons are 
still intact). Factors of time, climate, vegetation, and soil drainage are considered constant for each site. Similar drainage assumes that the channel incisions that isolated the terraces occurred at a similar time at each site. Parent material in the Uphapee drainage differs somewhat from parent material in the Tallapoosa, as the latter drains the Piedmont as well as the Coastal Plain. Differences are evidenced by a higher muscovite content in sands of the Tallapoosa sediments. For the moment, assume that parent-material differences do not materially alter soil development in the two watersheds. The following assumptions and computations are then used to assess soil (argillic) development: (1) eluvial and illuvial horizons have uniform particle-size distributions at time zero; (2) the amount of clay accumulated in illuvial horizons over time equals the amount of clay currently present in the upper eluvial horizon; and (3) illuviated clay is estimated by [(clay percentage in upper B horizon - clay percentage in A horizon) $\times$ bulk density of horizon $\times$ horizon thickness] for each horizon and summed for the illuvial horizons. If soil development is similar for all sites, the magnitude of these values should be similar for all sites (if assumptions 1 and 2 are valid).

A sample calculation for pedon 101-001 is as follows:

$(46.6-14.8)$ percent clay $\times 1.43 \mathrm{~g} / \mathrm{cm}^{3}$

$\times 22 \mathrm{~cm}=1,000 \mathrm{~g} / \mathrm{cm}^{2}$

The results for all four pedons are as follows:

\begin{tabular}{lllc}
\hline Pedon & $\begin{array}{c}\text { Sampled } \\
\text { as }^{1}\end{array}$ & $\begin{array}{c}\text { Clay, in } \mathrm{g} / \mathrm{cm}^{2} \\
\text { per horizon }\end{array}$ & $\begin{array}{c}\text { Illuviated total clay, } \\
\text { in } \mathrm{g} / \mathrm{cm}^{2}\end{array}$ \\
\hline $087-001 \ldots \ldots \ldots \ldots . . \mathrm{D}$ & $748+425+572$ & 1,745 \\
$087-002$ & $\ldots \ldots . \mathrm{P}$ & $815+750$ & 1,565 \\
$101-001$ & $\ldots \ldots \ldots \ldots \ldots . . . \mathrm{H}$ & 1,000 & 1,000 \\
$101-002 \ldots \ldots \ldots \ldots . . . \mathrm{D}$ & 194 & 194 \\
\hline
\end{tabular}

${ }^{1}$ D, Dystrochrept; P, Paleudult; H, Hapludult.

The results indicate widely divergent values for the four sites, and the quantities do not correspond with the degree of development suggested by the "Sampled as" classification. In summary, these calculations suggest that the clay increases from the $A$ horizons to the $B$ horizons are not associated with soil development or that there has not been enough time for pedogenic processes to alter the orginal sediment distribution.

\section{Stratigraphy versus Pedogenesis}

To assess soil development, scientists must decide to what degree pedogenic processes have made an imprint on the soil parent material. In fluvial settings, the parent material is characterized by particle-size distribution, stratification, mineralogy, and chemistry of the sediment.
Pedogenic development is evidenced by accumulation of organic matter that decreases downward from the surface, accumulation of clay in a subsurface (argillic) horizon, development of soil structure and (or) the obliteration of sedimentary structures, and changes in mineralogy or chemistry.

Sedimentary structure is obliterated by bioturbation, by shrink-swell activity if clay content is high enough, and by oxidation of detrital organic components. An argillic horizon is evidenced by subsurface accumulation of illuviated clay relative to the overlying horizons. Clay accumulates in an argillic horizon by alteration of material in place, by original deposition, and by illuviation of clay from the overlying horizons. Clay illuviation is evidenced by the presence of oriented clay cutans in pores and on soil structural (ped) surfaces. Observed illuvial clay cutans are noted by a " $\mathrm{t}$ " in a horizon designation. Strictly, the " $\mathrm{t}$ " indicates evidence of moved and deposited clay and is not sufficient in itself to identify an argillic horizon. Conversely, argillic horizons can and do develop without showing evidence of moved clay (Nettleton and others, 1969). Lack of oriented clay in upper B horizons may be because of degradation or because conditions were never right for deposition. If soil structural surfaces are unstable because of shrink-swell, clay cutans are destroyed.

In the fluvial setting of the present study, it is reasonable to assume that deposits are alluvium and have been emplaced no longer than 5,500 to 7,500 years, in accord with radiocarbon ages. Sediments within the soil profile could be younger if more than one episode of deposition postdates the dated carbonaceous material. Evidence of stratification (particle-size distribution among horizons) is distinct in pedons 087-001 (three episodes), 101-001 (three episodes, including overbank sedimentation), and 101-002 (three episodes, including overbank sedimentation) and is subtle in pedon 087-002 if it is present at all. Evidence of stratification can be assessed by computing the particle-size separates on a clay-free base as presented in table 7 .

Determining the degree of soil development is confounded when depositional strata show an increase in clay within the depth interval commonly associated with the development of an argillic horizon. Table 6 presents a summary of the intervals of clay maxima and contrasts those with intervals in which microscopic clay cutans are observed petrographically. There are significant increases in clay percentages at the tops of fining-upward sequences in each pedon. For example, in pedons $087-001$, there is a 12- to 27-percent clay increase at $73 \mathrm{~cm}$; in pedon 087-002, there is a 7- to 36-percent clay increase at $36 \mathrm{~cm}$; in pedon 101-001, there is a 14- to 47-percent clay increase at $22 \mathrm{~cm}$; and, in pedon 101-002, there is a 21 - to 38 -percent clay increase at $8 \mathrm{~cm}$. These intervals do not correspond to the 
intervals of petrographically identified clay cutans. The evidence for stratification in all these pedons suggests that the relative amounts of clay in their upper horizons result from deposition rather than pedogenic processes.

\section{CONCLUSIONS}

1. Evidence indicates minimal soil development and suggests that differences in clay content relate to stratigraphy and that there has been no significant alteration related to in situ formation of clay minerals.

2. There are differences in the mineralogies of sediments in the two river systems and associated differences in the chemistries of the sediments. However, these differences have had no measurable effect on soil development. Differences in chemical properties are related to differences in source sediments rather than to differences in soil development.

3. Data indicate that, even under the humid temperate to humid subtropical environment of the upper Coastal Plain of east-central Alabama, only minimal soil development is present in Holocene age alluvium that undergoes periodic flooding and sediment attrition. Some of the characteristic properties of these soils are (1) the dominance of $\mathrm{Bw}$ horizons rather than argillic horizons, (2) the irregular decrease in organic carbon and relatively high values $(>0.2$ percent) of organic carbon to depths of $150 \mathrm{~cm}$ or more, (3) the nonsystematic decrease of $\mathrm{SiO}_{2}$ relative to zirconium, and (4) the constancy of the $\mathrm{Fe}_{2} \mathrm{O}_{3}$ values with depth in each pedon.

4. Field and laboratory data indicate that all four sites should be classified as Fluventic Dystrochrepts. This determination was not arrived at by applying the key to soil orders as now used in Soil Taxonomy (Soil Survey Staff, 1975) but through field observations of the soils and the parent material at each site and as a result of laboratory analyses. The dilemma posed in classifying these fluvial soils needs to be addressed by soil taxonomists.

\section{REFERENCES CITED}

Altschuler, Z.S., Dwornik, E.J., and Kramer, H., 1963, Transformation of montmorillonite to kaolinite during weathering: Science, v. 141, p. 148-152.
Birkeland, P.W., 1984, Soils and geomorphology: New York, Oxford University Press, 372 p.

Harden, J.W., 1987, Soils developed in granitic alluvium near Merced, California: U.S. Geological Survey Bulletin 1590A, $65 \mathrm{p}$.

Karathanasis, A.D. 1982, Characteristics of naturally acid soil smectites: Auburn, Ala., Auburn University, unpublished Ph.D thesis, 217 p.

Karathanasis A.D., and Hajek, B.F.. 1983, Transformation of smectite to kaolinite in naturally acid soil systems: Structural and thermodynamic considerations: Soil Science Society of America Journal, v. 47, no. 1, p. 158-163.

Linsley, R.K., Jr., Kohler, M.A., and Paulhus, J.L., 1975, Hydrology for engineers: New York, McGraw-Hill, 482 p.

Markewich, H.W., and Christopher, R.A., 1982a, Pleistocene(?) and Holocene fluvial history of Uphapee Creek, Macon County, Alabama: U.S. Geological Survey Bulletin 1522, 16 p.

1982b, Geologic map of the LaPlace and Tuskegee Quadrangles, Macon, Tallapoosa, and Elmore Counties, Alabama: U.S. Geological Survey Miscellaneous Investigations Map I-1417, scale 1:48,000.

Nettleton, W.D., Flach, K.W., and Brasher, B.R., 1969, Argillic horizons without clay skins: Soil Science Society of America Journal, v. 33, no. 1, p. 121-125.

Nikiforoff, C.C., 1949, Weathering and soil evolution: Soil Science, v. 67, p. 219-230.

Shipp, D.L., 1985, A floristic analysis of Holocene leaf mats from Macon County, Alabama: Fairfax, Va., George Mason University, unpublished M.Sc. thesis, 138 p.

Soil Survey Staff, 1972, Soil Survey investigations report no. 1: Soil Survey laboratory methods and procedures for collecting samples: Washington, D.C., U.S. Department of Agriculture, Soil Conservation Service, $63 \mathrm{p}$.

1975, Soil taxonomy: Washington, D.C., U.S. Department of Agriculture, Soil Conservation Service, Agriculture Handbook No. 436, 754 p.

1981, Soil Survey manual no. 1: Washington, D.C., U.S. Department of Agriculture, Soil Conservation Service, unpublished revision of Agriculture Handbook No. 18, 107 p.

1986, Designations for master horizons and layers in soils: New York, Cornell University, Department of Agronomy, $16 \mathrm{p}$.

Sudom, M.D., and Arnaud, R.J., 1971, Use of quartz, zirconium, and titanium as indices in pedological studies: Canadian Journal of Soil Science, v. 51, p. 385-396. 

Tables 1-7 
Table 1. Analytical methods and units of expression for analyses conducted at the Soil Conservation Service National Soil Survey Laboratory, Lincoln, Nebr.

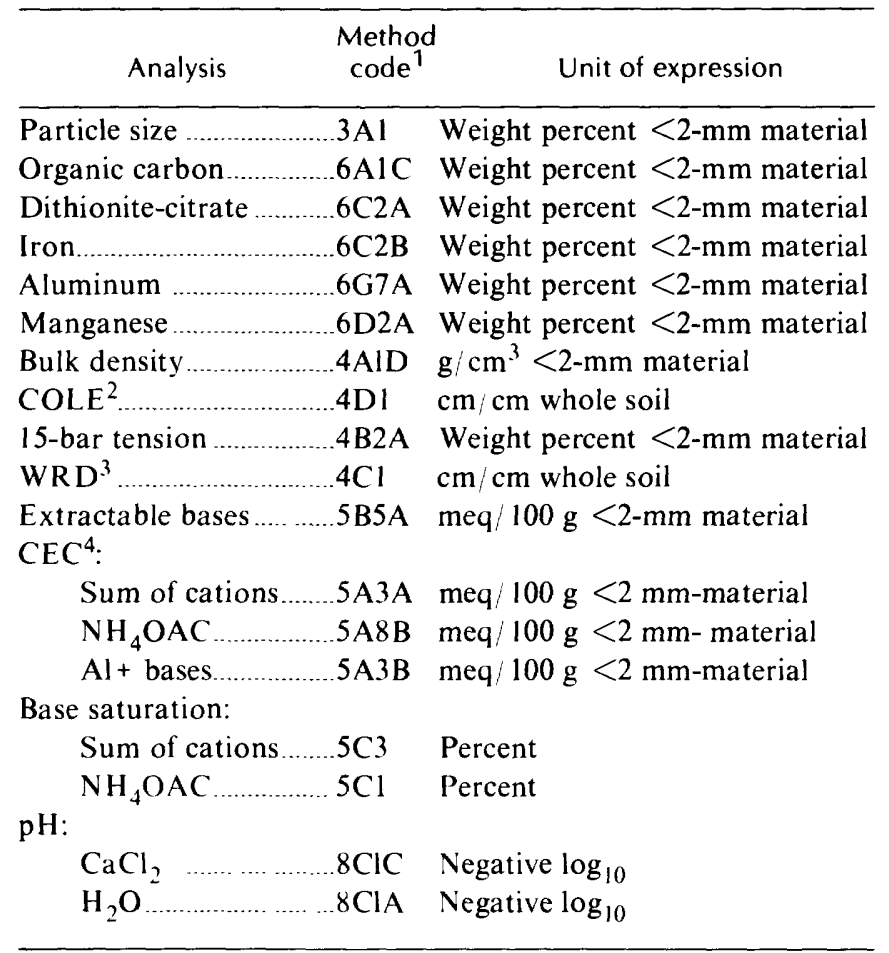

\footnotetext{
${ }_{2}^{1}$ Method codes from Soil Survey Staff (1972).

${ }^{2}$ Coefficient of linear extensibility.

${ }^{3}$ Water-retention difference.

${ }^{4}$ Cation exchange capacity.
} 
Table 2A. Field description of pedon S81AL- 087-001

[The Uphapee Creek A soil is developed in Holocene-age fluvial sediments and is classified as a fine loamy, mixed, thermic Fluventic Dystrochrept. The series is undesignated but was considered on the basis of field evidence to be closest to Riverview. Site location is in Macon County, Alabama, in SE $1 / 4$, sec. 17, T. 17 N., R. 24 E., Tuskegee 7.5-mınute quadrangle, on the flood plain of Uphapee Creek. The altitude of the site is $255 \mathrm{ft}(78 \mathrm{~m}$ ) above sea level. A radiocarbon age of $7.500 \mathrm{yr}$ B.P. (Markewich and Christopher. 1982a) was obtained from wood in a layer of organic detritus from near the base of the alluvial sediments about $500 \mathrm{ft}(150 \mathrm{~m})$ from the sample locality. The width of the flood plain at this locality is about 0.75 to $1 \mathrm{mi}(1-1.6 \mathrm{~km})$. No entry, no data]

\begin{tabular}{|c|c|c|c|c|c|c|c|}
\hline $\begin{array}{l}\text { Depth } \\
\text { (cm) }\end{array}$ & Horizon $^{1}$ & $\begin{array}{l}\text { Moist } \\
\text { color }\end{array}$ & Texture 4 & Structure $\mathrm{e}^{5}$ & $\begin{array}{l}\text { Clay } \\
\text { skins }\end{array}$ & Roots & Boundary ${ }^{6}$ \\
\hline $0-26 \ldots \ldots$ & Ap (Ap) & $10 Y R 4 / 3$ & fsl & Imsbk & None & & $\mathrm{cw}$ \\
\hline $26-47 \ldots \ldots$ & $\mathrm{B} 2 \mathrm{l}(\mathrm{Bw})$ & $\begin{array}{l}10 Y R 5 / 3 \\
10 Y R 4 / 3^{3}, 10 Y R 2 / 1^{3}\end{array}$ & fsl 1 & $3 \mathrm{mpr}, 1 \mathrm{msbk}$ & None & & $\mathrm{cw}$ \\
\hline $47-73 \ldots$. & $\mathrm{B} 22(\mathrm{Bw} 2)$ & $\begin{array}{l}10 \text { YR } 5 / 4 \\
7.5 Y R 5 / 4^{3}\end{array}$ & fisl & Imsbk, $2 \mathrm{msbk}$ & None & & as \\
\hline $73-97$ & $\mathrm{~B} 23 \mathrm{t}(\mathrm{Bw} 3)$ & $\begin{array}{l}7.5 Y R 4,4 \\
10 Y R 5 / 6^{3}, 10 Y R 5 / 2^{3}\end{array}$ & $\mathrm{cl}$ & $2 \mathrm{msbk}$ & & & cs \\
\hline $97-115$ & $\mathrm{~B} 24(\mathrm{Bw} 4)$ & $\begin{array}{l}10 \text { YR } 5 / 6 \\
10 \text { YR } 6 / 2^{3}, 10 Y R 5 / 8^{3}\end{array}$ & vfsl & $2 \mathrm{msbk}$ & None & & $\mathrm{cw}$ \\
\hline $115-130$ & $\mathrm{~B} 3(\mathrm{BC})$ & $\begin{array}{l}\text { 10YR } 5 / 6 \\
10 Y R 6 / 1^{3}, 10 Y R 6 / 8^{3}\end{array}$ & fst & Imsbk & None & & $\mathrm{gw}$ \\
\hline $130-170$ & $\mathrm{IlCl}(\mathrm{C} 1)$ & $\begin{array}{l}10 Y R 6 / 6 \\
10 Y R 6 / 3^{3}, 10 Y R 6 / 1^{3}\end{array}$ & Ifs & MA & None & & as \\
\hline $170-200$ & $1 \mathrm{IC} 2(\mathrm{C} 2)$ & $\begin{array}{ll}10 Y R 7 / 2 & \text { (uncoated) } \\
7.5 Y R ~ 4 / 4 & \text { (coated) }\end{array}$ & fs & SG & None & & \\
\hline
\end{tabular}

\footnotetext{
${ }_{2}^{1}$ New horizon designations, taken from Soil Conservation Service (1986), are given in parentheses.

2 Munsell notation.

3 Mottles.

4 fsl, fine sandy loam; cl, clay loam; vfsl, very fine sandy loam; lfs, loamy fine sand; fs, fine sand.

5 1, weak: 2, moderate; 3 , strong; $m$, medium; sbk, subangular blocky; pr, prismatic; MA, massive; SG, single grain.

6 cw, clear wavy; as, abrupt smooth; cs. clear smooth; gw, gradual wavy.
}

Table 2B. Textural analysis of pedon S81AL-087-001

[Grain size in millimeters; all other values in weight percent. VF, very fine; F, fine; M, medium; C, coarse; VC, very coarse; . analyzed but below detectable limits: TR, trace]

\begin{tabular}{|c|c|c|c|c|c|c|c|c|c|c|c|c|}
\hline \multirow[b]{2}{*}{$\begin{array}{l}\text { Depth } \\
\text { (cm) }\end{array}$} & \multirow[b]{2}{*}{ Horizon $^{1}$} & \multicolumn{3}{|c|}{ Total } & \multirow{2}{*}{$\frac{\text { Clay }}{\begin{array}{c}\mathrm{F} \\
(<.0002)\end{array}}$} & \multicolumn{2}{|c|}{ Silt } & \multicolumn{5}{|c|}{ Sand } \\
\hline & & $\begin{array}{l}\text { Clay } \\
(<.002)\end{array}$ & $\begin{array}{l}\text { Silt } \\
(.002- \\
.05)\end{array}$ & $\begin{array}{l}\text { Sand } \\
(.05- \\
2)\end{array}$ & & $\begin{array}{c}\mathrm{F} \\
(.002- \\
.02)\end{array}$ & $\begin{array}{c}\mathrm{C} \\
(.02- \\
.05)\end{array}$ & $\begin{array}{l}\text { VF } \\
(.05- \\
.10)\end{array}$ & $\begin{array}{c}F \\
(.10- \\
.25)\end{array}$ & $\begin{array}{c}M \\
(.25- \\
.50)\end{array}$ & $\begin{array}{c}C \\
(.50- \\
1.0)\end{array}$ & $\begin{array}{l}\text { VC } \\
(1.0- \\
2.0)\end{array}$ \\
\hline $0-26 \ldots$ & $A p(A p)$ & 7.4 & 24.7 & 67.9 & 3.3 & 7.8 & 16.9 & 49.1 & 16.1 & 1.7 & 0.8 & 0.2 \\
\hline $26-47$ & $B 21(B w 1)$ & 12.2 & 21.4 & 66.4 & 2.8 & 6.5 & 14.9 & 46.4 & 17.1 & 1.9 & .9 & .1 \\
\hline $47-73$. & $\mathrm{B} 22(\mathrm{Bw} 2)$ & 11.7 & 16.7 & 71.6 & 4.1 & 4.5 & 12.2 & 44.4 & 24.1 & 2.0 & 1.0 & .1 \\
\hline $73-97$. & $\mathrm{B} 23 \mathrm{t}(\mathrm{Bw} 3)$ & 27.1 & 31.8 & 41.1 & 15.2 & 12.3 & 19.5 & 29.8 & 6.6 & 3.1 & 1.4 & .2 \\
\hline $97-115 \ldots$ & $B 24(B w 4)$ & 22.5 & 34.6 & 42.9 & 11.9 & 11.4 & 23.2 & 31.3 & 8.9 & 1.4 & 1.2 & .1 \\
\hline $115-130$ &.. $\mathrm{~B} 3(\mathrm{BC})$ & 16.7 & 21.9 & 61.4 & 8.5 & 5.7 & 16.3 & 33.8 & 25.8 & 1.6 & .2 & TR \\
\hline $130-170$ &. $.1 \mathrm{ICl}(\mathrm{C} 1)$ & 8.5 & 8.5 & 83.0 & 6.5 & .8 & 7.7 & 42.8 & 28.4 & 10.5 & 1.3 & TR \\
\hline $170-200$ & $.11 C 2(C 2)$ & 1.2 & 4.4 & 94.4 & & .4 & 4.0 & 13.2 & 31.3 & 33.4 & 14.4 & 2.1 \\
\hline
\end{tabular}

\footnotetext{
${ }^{1}$ New horizon designations, taken from Soil Conservation Service (1986), are given in parentheses.
} 
Table 2C. Physical and chemical analyses of pedon S81AL-087-001

[Units of measure for all values given in table I. --, not detected; TR, trace]

\begin{tabular}{|c|c|c|c|c|c|c|c|c|c|c|}
\hline \multirow{3}{*}{$\begin{array}{l}\text { Depth } \\
(\mathrm{cm})\end{array}$} & \multirow[b]{3}{*}{ Horizon $^{1}$} & \multirow{3}{*}{$\underset{C}{\text { Organic }}$} & \multirow{3}{*}{$\begin{array}{c}\text { Total } \\
\mathrm{N}\end{array}$} & \multicolumn{2}{|c|}{ Dithionite-citrate } & \multirow{2}{*}{\multicolumn{2}{|c|}{ Ratio clay }} & \multirow{2}{*}{\multicolumn{2}{|c|}{ Bulk density }} & \multirow[b]{3}{*}{$\operatorname{COLE}^{4}$} \\
\hline & & & & \multirow{2}{*}{$\begin{array}{c}\text { Extractable } \\
\mathrm{Fe}\end{array}$} & \multirow{2}{*}{$\begin{array}{c}\text { Extractable } \\
\mathrm{Al}\end{array}$} & & & & & \\
\hline & & & & & & $\mathrm{CEC}^{2}$ & $15 \mathrm{bar}^{3}$ & $1 / 3 \mathrm{bar}$ & Oven dry & \\
\hline $0-26$. & $A p(A p)$ & 0.82 & 0.065 & 0.3 & 0.1 & 0.78 & 0.57 & 1.46 & 1.47 & 0.002 \\
\hline $26-47$. & B2l (Bwl) & .45 & .034 & .4 & .1 & .44 & .40 & 1.36 & 1.37 & .002 \\
\hline 47-73. & $\mathrm{B} 22(\mathrm{Bw} 2)$ & .29 & .023 & .3 & .1 & .44 & .38 & 1.43 & 1.43 & -- \\
\hline $73-97 \ldots$ & $\mathrm{B} 23 \mathrm{t}(\mathrm{Bw} 3)$ & .30 & .034 & .8 & .2 & .47 & .38 & 1.42 & 1.51 & .021 \\
\hline $97-115 \ldots$ & B24 (Bw4) & .25 & - & .6 & .2 & .48 & .40 & 1.48 & 1.53 & .011 \\
\hline $115-130$. & B3 (BC) & .21 & -- & .4 & .1 & .46 & .37 & 1.53 & 1.55 & .004 \\
\hline $130-170$. &.. $\mathrm{IICl}(\mathrm{C} 1)$ & .16 & -- & .2 & .1 & .39 & .31 & 1.46 & 1.47 & .002 \\
\hline $170-200$. & $.1 \mathrm{IC} 2(\mathrm{C} 2)$ & .14 & -- & .1 & $\mathrm{TR}$ & .92 & .92 & 1.51 & 1.51 & -- \\
\hline
\end{tabular}

\begin{tabular}{|c|c|c|c|c|c|c|c|c|c|c|c|}
\hline \multirow{3}{*}{$\begin{array}{l}\text { Depth } \\
\text { (cm) }\end{array}$} & \multirow[b]{3}{*}{ Horizon $^{1}$} & \multirow{2}{*}{\multicolumn{2}{|c|}{ Water content }} & \multirow[b]{3}{*}{$W R D^{5}$} & \multirow[b]{3}{*}{$\mathrm{Ca}$} & \multicolumn{4}{|c|}{$\mathrm{NH}_{4} \mathrm{OAC}$ extractable bases } & \multirow[b]{3}{*}{ Acidity } & \multirow{3}{*}{$\begin{array}{c}\text { Extractable } \\
\text { Al }\end{array}$} \\
\hline & & & & & & & & & & & \\
\hline & & $1 / 3$ bar & $15 \mathrm{bar}^{3}$ & & & $\mathrm{Mg}$ & $\mathrm{Na}$ & K & bases & & \\
\hline $0-26$ & Ap (Ap) & 12.2 & 4.2 & 0.12 & 3.3 & 0.5 & TR & 0.2 & 4.0 & 2.3 & 0.3 \\
\hline $26-47$ & $\mathrm{~B} 2 \mathrm{l}(\mathrm{Bw} 1)$ & 12.6 & 4.9 & .10 & 2.4 & .3 & -- & .1 & 2.8 & 3.0 & 1.6 \\
\hline $47-73$. & $\mathrm{B} 22(\mathrm{Bw} 2)$ & 11.8 & 4.5 & .10 & .5 & .1 & - - & .2 & .8 & 4.5 & 3.6 \\
\hline $73-97 \ldots$ & B23t $(\mathrm{Bw} 3)$ & 22.9 & 10.3 & .18 & .5 & .2 & -- & .1 & .8 & 12.4 & 9.8 \\
\hline $97-115$ & B24 (Bw4) & 20.6 & 8.9 & .17 & .1 & .2 & TR & .1 & .4 & 12.8 & 8.9 \\
\hline $115-130$ & B3 $(\mathrm{BC})$ & 13.9 & 6.1 & .12 & TR & .2 & $\mathrm{TR}$ & .1 & .3 & 8.9 & 5.9 \\
\hline $130-170$ &. $.11 \mathrm{Cl}(\mathrm{Cl})$ & 10.3 & 2.6 & .11 & -- & .1 & TR & .1 & .2 & 4.7 & 2.5 \\
\hline $170-200$ & $11 C 2$ (C2) & 8.8 & 1.1 & .12 & TR & $\mathrm{TR}$ & - & TR & $\mathrm{TR}$ & 1.3 & .9 \\
\hline
\end{tabular}

\begin{tabular}{|c|c|c|c|c|c|c|c|c|c|c|}
\hline \multirow{3}{*}{$\begin{array}{l}\text { Depth } \\
\text { (cm) }\end{array}$} & \multirow[b]{3}{*}{ Horizon $^{1}$} & \multicolumn{3}{|c|}{$\mathrm{CEC}^{2}$} & \multirow{3}{*}{$\underset{\text { saturation }}{\mathrm{Al}}$} & & & \multicolumn{3}{|c|}{$\mathrm{pH}$} \\
\hline & & \multirow{2}{*}{$\begin{array}{l}\text { Sum of } \\
\text { cations }\end{array}$} & \multirow[b]{2}{*}{$\mathrm{NH}_{4} \mathrm{OAC}$} & \multirow{2}{*}{$\begin{array}{c}\text { Bases + } \\
\mathrm{Al}\end{array}$} & & \multicolumn{2}{|c|}{ Base saturation } & \multirow[b]{2}{*}{$\mathrm{KCl}$} & \multirow{2}{*}{$\begin{array}{c}\mathrm{CaCl}_{2} \\
(1: 2)\end{array}$} & \multirow{2}{*}{$\begin{array}{l}\mathrm{H}_{2} \mathrm{O} \\
(1: 1\end{array}$} \\
\hline & & & & & & Sum & $\mathrm{NH}_{4} \mathrm{OAC}$ & & & \\
\hline $0-26$. & Ap (Ap) & 6.3 & 5.8 & 4.3 & 7 & 63 & 69 & 4.3 & 4.6 & 5.4 \\
\hline $26-47$ &. $\mathrm{~B} 2 \mathrm{l}(\mathrm{B} \cup 1)$ & 5.8 & 5.4 & 4.4 & 36 & 48 & 52 & 4.0 & 4.6 & 5.2 \\
\hline $47-73$ & $\mathrm{~B} 22(\mathrm{Bw} 2)$ & 5.3 & 5.2 & 4.4 & 82 & 15 & 15 & 3.8 & 4.0 & 4.7 \\
\hline $73-97$ & $\ldots \mathrm{B} 23 \mathrm{t}(\mathrm{Bw} 3)$ & 13.2 & 12.7 & 10.6 & 92 & 6 & 6 & 3.5 & 4.2 & 4.5 \\
\hline $97-115$. & B24 $(\mathrm{Bw} 4)$ & 13.2 & 10.9 & 9.3 & 96 & 3 & 4 & 3.4 & 4.1 & 4.5 \\
\hline $115-130$ & $\ldots \mathrm{B} 3(\mathrm{BC})$ & 9.2 & 7.6 & 6.2 & 95 & 3 & 4 & 3.4 & 4.3 & 4.5 \\
\hline $130-170$ & $\ldots 1 \mathrm{ICl}(\mathrm{Cl})$ & 4.9 & 3.3 & 2.7 & 93 & 4 & 6 & 3.7 & 3.9 & 4.5 \\
\hline $170-200$ & $\ldots 11 C 2(\mathrm{C} 2)$ & 1.3 & 1.1 & .9 & 100 & -- & 2 & 3.9 & 4.1 & 4.7 \\
\hline
\end{tabular}

\footnotetext{
${ }^{1}$ New horizon designations, taken from Soil Conservation Service (1986), are given in parentheses.

${ }^{2}$ Cation exchange capacity.

${ }^{3}$ Water content at 15-bar pressure.

${ }^{4}$ Coefficient of linear extensibility.

${ }^{5}$ Water-retention difference.
} 
Table 2D. Optical mineralogy of very fine sand fraction of selected horizons of pedon S81AL-087-001

[Potassium feldspar is the dominant weatherable mineral in all horizons, for both count and adjusted count. TR, trace]

\begin{tabular}{|c|c|c|}
\hline Mineral & $\begin{array}{c}\text { Count } \\
\text { (percent) }\end{array}$ & $\begin{array}{l}\text { Adjusted count } \\
\text { (percent) }\end{array}$ \\
\hline \multicolumn{3}{|c|}{ Horizon B21 (Bw1), ${ }^{1} 26-47 \mathrm{~cm}$, very fine sand } \\
\hline Quart7 & 78 & 78 \\
\hline Potassium feldspar ............... & 19 & 19 \\
\hline 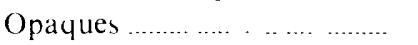 & 1 & 1 \\
\hline 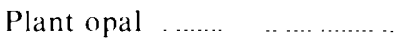 & 1 & 1 \\
\hline 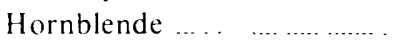 & 1 & 1 \\
\hline Kadinite .......... . .......... & TR & TR \\
\hline 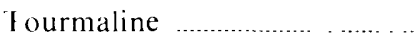 & TR & TR \\
\hline Muscovite $\ldots \ldots \ldots \ldots$ & TR & TR \\
\hline Epidote $\ldots \ldots \ldots \ldots$ & TR & TR \\
\hline 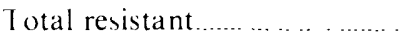 & 80 & 80 \\
\hline
\end{tabular}

\begin{tabular}{|c|c|c|}
\hline \multicolumn{3}{|c|}{ Horizon B23t (Bw3), ${ }^{1} 73-97 \mathrm{~cm}$, very fine sand } \\
\hline Quart7. . & 77 & 77 \\
\hline Potassium feldspar & 19 & 19 \\
\hline 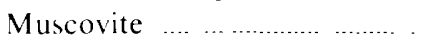 & 2 & TR \\
\hline 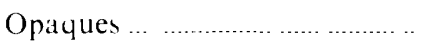 & 2 & 2 \\
\hline 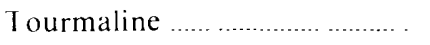 & TR & $\mathrm{TR}$ \\
\hline Zircon & TR & TR \\
\hline 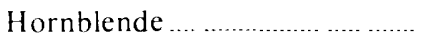 & TR & TR \\
\hline Kaolinite . & TR & $\mathrm{TR}$ \\
\hline Total resistant ... & 79 & 81 \\
\hline
\end{tabular}

\begin{tabular}{|c|c|c|}
\hline \multicolumn{3}{|c|}{ Horizon $2 \mathrm{C} 2(\mathrm{C} 2),,^{1} 170-200 \mathrm{~cm}$, very fine sand } \\
\hline 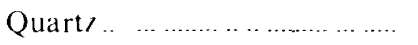 & 82 & 83 \\
\hline Potassium feldspar .............. & 14 & 14 \\
\hline 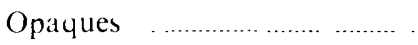 & 1 & 1 \\
\hline 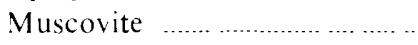 & 1 & TR \\
\hline 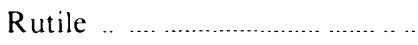 & TR & TR \\
\hline Zircon $\quad \ldots . . . \ldots \ldots \ldots \ldots \ldots \ldots$ & TR & TR \\
\hline Tourmaline $\ldots \ldots \ldots \ldots \ldots \ldots \ldots$ & TR & TR \\
\hline Epidote & TR & TR \\
\hline 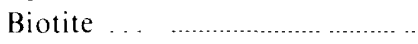 & TR & TR \\
\hline 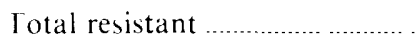 & 83 & 84 \\
\hline
\end{tabular}

\footnotetext{
Tew horizon designations, taken from Soil Conservation Service (1986), are in parentheses.
}

Table 2E. Bulk chemistry of pedon S81AL-087-001

[All values in weight percent except for $\mathrm{Fe}_{2} \mathrm{O}_{3} / \mathrm{Al}_{2} \mathrm{O}_{3}$, which is a ratio. New horizon designations, taken from Soil Conservation Service ( 1986 ), are in parentheses]

\begin{tabular}{|c|c|c|c|c|c|c|c|c|}
\hline \multirow[b]{2}{*}{ Major oxide } & \multicolumn{8}{|c|}{ Horizon } \\
\hline & $\operatorname{AP}(A p)$ & $\mathrm{B} 21$ (Bw1) & $\mathrm{B} 22(\mathrm{Bw} 2)$ & B23t (Bw3) & B24 (Bw4) & $\mathrm{B} 3(\mathrm{BC})$ & $2 \mathrm{C} 1(\mathrm{C} 1)$ & $2 \mathrm{C} 2(\mathrm{C} 2)$ \\
\hline 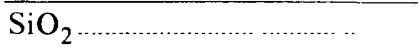 & 86.9 & 86.7 & 87.9 & 77.7 & 80.0 & 85.2 & 82.1 & 83.1 \\
\hline $\mathrm{Al}_{2} \mathrm{O}_{3}$ & 6.4 & 6.7 & 6.4 & 11.0 & 10.0 & 7.2 & 9.5 & 8.7 \\
\hline $\mathrm{Fe}_{2} \mathrm{O}_{3}$ & 1.1 & 1.2 & 1.2 & 2.6 & 2.2 & 1.6 & 2.2 & 2.4 \\
\hline $\mathrm{CaO}$ & .2 & .2 & .2 & .2 & .1 & .1 & .3 & .3 \\
\hline $\mathrm{K}_{2} \mathrm{O} \ldots \ldots$ & 1.9 & 1.8 & 1.6 & 1.8 & 1.9 & 1.7 & 2.4 & 2.5 \\
\hline $\mathrm{TiO}_{2} \ldots$ & .7 & .7 & .7 & .8 & .8 & .7 & 1.6 & 1.7 \\
\hline $\mathrm{MnO}$ & .04 & .04 & .05 & .05 & .12 & .02 & .08 & .1 \\
\hline $\mathrm{Fe}_{2} \mathrm{O}_{3} / \mathrm{Al}_{2} \mathrm{O}_{3} \ldots \ldots$ & .17 & .18 & .19 & .24 & .22 & .22 & .23 & .28 \\
\hline
\end{tabular}


Table 3A. Field description of pedon S81AL-087-002

[The Uphapee Creek B soil is developed in Holocene-age fluvial sediments and was classified on the basis of field evidence as a clayey mixed. thermic Aquic Paleudult (data support clayey, mixed, thermic Hapludult or Ochraquult). The series is undesignated. Site 2 is located at the section corner of secs. 1, 2,11, and 12. For this report, it is located at an altitude of $242 \mathrm{ft}(74 \mathrm{~m})$ above sea level. Tuskegee 7.5 -minute quadrangle, $20+\mathrm{ft}(7 \mathrm{~m})$ north of Uphapee Creek, sec. 1, T. 17 N., R. 23 E., Macon County, Alabama. Wood from organic debris exposed in the bank of Uphapee Creek at the base of the alluvium terrace level has been dated at 6.500 years (Markewich and Christopher. 1982a). This pit was pumped to describe the profile and repumped to sample. No entry, no data]

\begin{tabular}{|c|c|c|c|c|c|c|c|}
\hline $\begin{array}{l}\text { Depth } \\
\text { (cm) }\end{array}$ & Horizon ${ }^{1}$ & $\begin{array}{l}\text { Moist } \\
\text { color }^{3}\end{array}$ & Texture $^{5}$ & Structure $^{6}$ & $\begin{array}{l}\text { Clay } \\
\text { skins }\end{array}$ & Roots & Boundary ${ }^{7}$ \\
\hline $0-20 \ldots$ & $A l(A)$ & $10 Y R 3 / 2$ & fs l & $\operatorname{lmgr}$ & & & $\mathrm{cs}$ \\
\hline $20-36 \ldots$ & $A 2(E)$ & 10 YR $5 / 3$ & fsl & $\operatorname{lmgr}$ & & & $\mathrm{cw}$ \\
\hline $36-58$. & $\mathrm{B} 21(\mathrm{Bw})$ & $\begin{array}{l}5 Y R 4 / 4 \\
\text { 10YR } 6 / 2^{4}\end{array}$ & $\mathrm{cl}$ & Imsbk & & & $\mathrm{cw}$ \\
\hline $58-78 \ldots$ & B22tb (Bwgl) & $\begin{array}{l}\text { 10YR 6/2 } \\
5 \text { Y R 5/6 }\end{array}$ & $\mathrm{c}$ & $2 \mathrm{mabk}$ & & & gs \\
\hline $78-112$ & $\mathrm{~B} 23 \mathrm{tg}^{2}(\mathrm{Bwg} 2)$ & $\begin{array}{l}10 Y R 6 / 1 \\
5 Y R 5 / 6^{4}, 7.5 Y R 5 \cdot 8^{4}\end{array}$ & $\mathrm{c}$ & $\begin{array}{l}3 \mathrm{cpr} \\
3 \mathrm{mabk}\end{array}$ & & & \\
\hline $112-146$ & $\mathrm{~B} 23 \operatorname{tg}^{2}(\mathrm{Btg} 1)$ & $\begin{array}{l}\text { 10YR 6:1 } \\
5 \text { YR } 5,6^{4}, 7.5 \text { YR } 58^{4}\end{array}$ & c & $\begin{array}{l}3 \mathrm{cpr} \\
3 \mathrm{mabk}\end{array}$ & & & $\mathrm{ci}$ \\
\hline $146-176$ & B24t (Btg2) & $\begin{array}{l}10 Y R 6 / 1 \\
7.5 Y R 58^{4}\end{array}$ & sc & $2 \mathrm{msbk}$ & & & aw \\
\hline $206-230$ & $.11 C(C 1)$ & & g & SG & & & \\
\hline
\end{tabular}

${ }_{2}^{1}$ New horizon designations, taken from Soil Conservation Service (1986), are given in parentheses.

${ }^{2}$ Horizon split for sampling.

${ }^{3}$ Munsell notation.

${ }^{4}$ Mottles.

$5_{\mathrm{fsl}}$, fine sandy loam; cl, clay loam; c, clay; sc, sandy clay; $\mathrm{g}$, gravel.

${ }^{6}$, weak; 2 . moderate; 3 , strong; m. medium; c, coarse; gr, granular; sbk, subangular blocky; abk, angular blocky; pr, prismatic; SG, single grain.

${ }^{7}$ cs. clear smooth; cw, clear wavy; gs, gradual smooth; ci, clear irregular; aw, abrupt wavy.

Table 3B. Textural analysis of pedon S81AL-087-002

[Grain size in millimeters; all other values in weight percent. VF, very fine; F, fine; M, medium; C, coarse; VC, very coarse]

\begin{tabular}{|c|c|c|c|c|c|c|c|c|c|c|c|c|}
\hline \multirow[b]{2}{*}{$\begin{array}{l}\text { Depth } \\
(\mathrm{cm})\end{array}$} & \multirow[b]{2}{*}{ Horizon $^{1}$} & \multicolumn{3}{|c|}{ Total } & \multirow{2}{*}{ 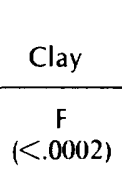 } & \multicolumn{2}{|c|}{ Silt } & \multicolumn{5}{|c|}{ Sand } \\
\hline & & $\begin{array}{c}\text { Clay } \\
(<.002)\end{array}$ & $\begin{array}{l}\text { Silt } \\
(.002- \\
.05)\end{array}$ & $\begin{array}{l}\text { Sand } \\
(.05- \\
2)\end{array}$ & & $\begin{array}{c}F \\
(.002- \\
.02)\end{array}$ & $\begin{array}{c}\mathrm{C} \\
(.02- \\
.05)\end{array}$ & $\begin{array}{c}\text { VF } \\
(.05- \\
.10)\end{array}$ & $\begin{array}{c}F \\
(.10- \\
.25)\end{array}$ & $\begin{array}{l}M \\
(.25- \\
.50)\end{array}$ & $\begin{array}{c}\mathrm{C} \\
(.50- \\
1.0)\end{array}$ & $\begin{array}{l}\text { VC } \\
(1.0- \\
2.0)\end{array}$ \\
\hline $0-20 \ldots \ldots$ & . Al (A) & 7.8 & 26.7 & 65.5 & 1.7 & 13.6 & 13.1 & 26.7 & 19.2 & 7.8 & 8.1 & 3.7 \\
\hline $20-36 \ldots$ & A 2 (E) & 7.3 & 26.6 & 66.1 & 2.4 & 15.0 & 11.6 & 29.5 & 19.7 & 7.8 & 6.1 & 3.0 \\
\hline $36-58$. & B2lt (Bw) & 36.1 & 24.0 & 39.9 & 16.8 & 13.6 & 10.4 & 18.3 & 11.3 & 5.5 & 3.6 & 1.2 \\
\hline $58-78 \ldots$ & B22tg $(B w g l)$ & 50.1 & 20.2 & 29.7 & 26.5 & 13.3 & $6: 9$ & 10.5 & 8.4 & 6.1 & 3.6 & 1.1 \\
\hline $78-112 \ldots$ & B23tg (Bwg2) & 40.8 & 20.2 & 39.0 & 21.4 & 12.4 & 7.8 & 14.2 & 11.4 & 7.4 & 4.4 & 1.6 \\
\hline $112-146$ & $\mathrm{~B} 23 \operatorname{tg}(\mathrm{Btgl})$ & 40.1 & 16.8 & 43.1 & 16.5 & 11.2 & 5.6 & 14.3 & 13.3 & 10.4 & 4.4 & .7 \\
\hline $146-176$ & B24tg (Btg2) & 26.6 & 15.8 & 57.6 & 14.3 & 10.2 & 5.6 & 18.4 & 17.3 & 13.1 & 6.6 & 2.2 \\
\hline
\end{tabular}

\footnotetext{
${ }^{1}$ New horizon designations, taken from Soil Conservation Service (1986), are given in parentheses.
} 
Table 3C. Physical and chemical analyses of pedon S81AL-087-002

[Units of measure for all values given in table 1. - , not detected; no entry, not analyzed; TR, trace]

\begin{tabular}{|c|c|c|c|c|c|c|c|c|c|c|}
\hline \multirow{3}{*}{$\begin{array}{l}\text { Depth } \\
\text { (cm) }\end{array}$} & \multirow[b]{3}{*}{ Horizon ${ }^{1}$} & \multirow{3}{*}{$\underset{C}{\text { Organic }}$} & \multirow{3}{*}{$\stackrel{\text { Total }}{N}$} & \multicolumn{2}{|c|}{ Dithionite-citrate } & \multirow{2}{*}{\multicolumn{2}{|c|}{ Ratio clay }} & \multirow{2}{*}{\multicolumn{2}{|c|}{ Bulk density }} & \multirow[b]{3}{*}{$\mathrm{COLE}^{4}$} \\
\hline & & & & \multirow{2}{*}{$\begin{array}{c}\text { Extractable } \\
\mathrm{Fe}\end{array}$} & \multirow{2}{*}{$\begin{array}{c}\text { Extractable } \\
\text { Al }\end{array}$} & & & & & \\
\hline & & & & & & $\mathrm{CEC}^{2}$ & $15 \mathrm{bar}^{3}$ & $1 / 3 \mathrm{bar}$ & Oven dry & \\
\hline $0-20 \ldots \ldots$ & $\mathrm{Al}(\mathrm{A})$ & 1.48 & 0.064 & 0.2 & 0.1 & 0.81 & 0.44 & 1.44 & 1.46 & 0.005 \\
\hline $20-36 \ldots$ & A $2(E)$ & .56 & .024 & .2 & $\mathrm{TR}$ & .44 & .36 & 1.6 .3 & 1.64 & .002 \\
\hline $36-58$ & $\mathrm{~B} 21 \mathrm{t}(\mathrm{Bw})$ & .41 & .028 & .8 & .2 & .34 & .36 & 1.51 & 1.67 & .034 \\
\hline $58-78$ & B $22 \operatorname{tg}(\mathrm{Bwg} 1)$ & .31 & .027 & 1.1 & .2 & .37 & .34 & 1.47 & 1.75 & .059 \\
\hline $8-112 \ldots$ & B23tg (Bwg2) & .26 & -- & .7 & .2 & .37 & .34 & 1.53 & 1.69 & .033 \\
\hline $112-146$ & B23tg $(B \operatorname{tg} 1)$ & .26 & -. & .7 & .2 & .40 & .34 & 1.50 & - & \\
\hline $146-176$ & $\mathrm{~B} 24 \mathrm{t}(\mathrm{Btg} 2)$ & .24 & & 6 & .1 & .40 & .38 & 1.61 & 1.76 & .030 \\
\hline
\end{tabular}

\begin{tabular}{|c|c|c|c|c|c|c|c|c|c|c|c|}
\hline \multirow[b]{2}{*}{$\begin{array}{l}\text { Depth } \\
(\mathrm{cm})\end{array}$} & \multirow[b]{2}{*}{ Horizon $^{1}$} & \multicolumn{2}{|c|}{ Water content } & \multirow[b]{2}{*}{ WRD 5} & \multicolumn{5}{|c|}{$\mathrm{NH}_{4} \mathrm{OAC}$ extractable bases } & \multirow[b]{2}{*}{ Acidity } & \multirow[b]{2}{*}{$\begin{array}{c}\text { Extractable } \\
\text { Al }\end{array}$} \\
\hline & & 1/3 bar & 15 bar $^{3}$ & & $\mathrm{Ca}$ & $\mathrm{Mg}$ & $\mathrm{Na}$ & $\mathrm{K}$ & $\begin{array}{l}\text { Sum of } \\
\text { bases }\end{array}$ & & \\
\hline $0-20$. & Al (A) & 16.8 & 3.4 & 0.19 & 0.4 & 0.3 & -- & 0.1 & 0.8 & 6.8 & 1.5 \\
\hline $20-36$ & $\mathrm{~A} 2(\mathrm{E})$ & 13.1 & 2.6 & .17 & .3 & .2 & -- & .1 & .6 & 3.0 & 1.0 \\
\hline $36-58$ & $\mathrm{~B} 2 \mathrm{lt}(\mathrm{Bw})$ & 21.0 & 12.9 & .12 & 1.3 & 1.2 & TR & .2 & 2.7 & 11.0 & 6.6 \\
\hline $58-78$ & $B 22 \operatorname{tg}(B w g l)$ & 27.3 & 17.0 & .15 & .9 & 1.7 & $\mathrm{TR}$ & .2 & 2.8 & 18.1 & 11.6 \\
\hline $78-112$ & $\mathrm{~B} 23 \operatorname{tg}(\mathrm{Bwg} 2)$ & 23.3 & 13.7 & .15 & .1 & 1.0 & .1 & .2 & 1.4 & 15.6 & 10.5 \\
\hline $112-146$ & $\mathrm{~B} 23 \operatorname{tg}(\mathrm{B} \operatorname{tg} \mathrm{l})$ & & 13.7 & & TR & 1.0 & $\mathrm{TR}$ & .2 & 1.2 & 16.7 & 11.5 \\
\hline $146-176$ & B24t (Btg2) & 21.1 & 10.1 & .17 & TR & .5 & .1 & .1 & .7 & 12.8 & 8.9 \\
\hline
\end{tabular}

\begin{tabular}{|c|c|c|c|c|c|c|c|c|c|c|}
\hline \multirow{3}{*}{$\begin{array}{l}\text { Depth } \\
(\mathrm{cm})\end{array}$} & \multirow[b]{3}{*}{ Horizon $^{1}$} & \multicolumn{3}{|c|}{$\mathrm{CEC}^{2}$} & \multirow{3}{*}{$\begin{array}{c}\mathrm{Al} \\
\text { saturation }\end{array}$} & & & \multicolumn{3}{|c|}{$\mathrm{pH}$} \\
\hline & & \multirow{2}{*}{$\begin{array}{l}\text { Sum of } \\
\text { cations }\end{array}$} & \multirow[b]{2}{*}{$\mathrm{NH}_{4} \mathrm{OAC}$} & \multirow{2}{*}{$\begin{array}{c}\text { Bases + } \\
\text { Al }\end{array}$} & & \multicolumn{2}{|c|}{ Base saturation } & \multirow[b]{2}{*}{$\mathrm{KCl}$} & \multirow{2}{*}{$\begin{array}{c}\mathrm{CaCl}_{2} \\
(1: 2)\end{array}$} & \multirow{2}{*}{$\begin{array}{l}\mathrm{H}_{2} \mathrm{O} \\
(1: 1)\end{array}$} \\
\hline & & & & & & Sum & $\mathrm{NH}_{4} \mathrm{OAC}$ & & & \\
\hline $0-20 \ldots \ldots$ & Al (A) & 7.6 & 6.3 & 2.3 & 65 & 11 & 13 & 3.8 & 4.5 & 4.7 \\
\hline $20-36 \ldots$ & $A 2(E)$ & 3.6 & 3.2 & 1.6 & 63 & 17 & 19 & 3.9 & 4.7 & 5.0 \\
\hline $36-58$ & $\mathrm{~B} 2 \mathrm{lt}(\mathrm{Bw})$ & 13.9 & 12.1 & 9.3 & 71 & 19 & 22 & 3.4 & 4.4 & 4.7 \\
\hline $58-78 \ldots$ & B22tg (Bwgl) & 20.9 & 18.6 & 14.4 & 81 & 13 & 15 & 3.3 & 4.1 & 4.5 \\
\hline $78-112 \ldots$ & B23tg (Bwg2) & 17.0 & 15.1 & 11.9 & 88 & 8 & 9 & 3.3 & 4.0 & 4.5 \\
\hline $112-146$ & B23tg (Btgl) & 17.9 & 16.2 & 12.7 & 91 & 7 & 7 & 3.2 & 4.0 & 4.3 \\
\hline $146-176$ & $B 24 t(B \operatorname{tg} 2)$ & 13.5 & 12.2 & 9.6 & 93 & 5 & 6 & 3.1 & 3.7 & 4.3 \\
\hline
\end{tabular}

\footnotetext{
'New horizon designations, taken from Soil Conservation Service (1986), are given in parentheses.

${ }^{2}$ Cation exchange capacity.

${ }^{3}$ Water content at 15 -bar pressure.

${ }^{4}$ Coefficient of linear extensibility.

${ }^{5}$ Water-retention difference.
} 
Table 3D. Optical mineralogy of very fine sand fraction of selected horizons of pedon S81AL-087-002

[Potassium feldspar is the dominant weatherable mineral in all horizons. for both count and adjusted count. TR, trace]

\begin{tabular}{|c|c|c|}
\hline Mineral & $\begin{array}{c}\text { Count } \\
\text { (percent) }\end{array}$ & $\begin{array}{l}\text { Adjusted count } \\
\text { (percent) }\end{array}$ \\
\hline \multicolumn{3}{|c|}{ Horizon B21t $(\mathrm{Bw}),{ }^{1} 22-47 \mathrm{~cm}$, very fine sand } \\
\hline Quartz & 80 & 81 \\
\hline Potassium feldspar & 16 & 17 \\
\hline Muscovite & 2 & TR \\
\hline Opaques & 1 & 1 \\
\hline Epidote & 1 & 1 \\
\hline Zircon & $\mathrm{TR}$ & TR \\
\hline Kaolinite & $\mathrm{TR}$ & TR \\
\hline Rutile & TR & TR \\
\hline Plant opal & TR & TR \\
\hline Total resistant & 81 & 82 \\
\hline
\end{tabular}

Horizon B23tg (Bwg2), ${ }^{1} 78-112 \mathrm{~cm}$, very fine sand

\begin{tabular}{|c|c|c|}
\hline Quartz & 80 & 82 \\
\hline Potassium feldspar ......................... & 15 & 15 \\
\hline Muscovite & 3 & TR \\
\hline Zircon & 1 & 1 \\
\hline 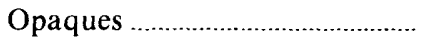 & 1 & 1 \\
\hline Tourmaline & $\mathrm{TR}$ & TR \\
\hline Epidote & TR & TR \\
\hline Plant opal & TR & TR \\
\hline Total resistant & 82 & 84 \\
\hline
\end{tabular}

\footnotetext{
${ }^{\mathrm{I}}$ New horizon designations, taken from Soil Conservation Service (1986), are in parentheses.
}

Table 3E. Bulk chemistry of pedon S81AL-087-002

[All values in weight percent except for $\mathrm{Fe}_{2} \mathrm{O}_{3} / \mathrm{Al}_{2} \mathrm{O}_{3}$, which is a ratio. New horion designations, taken from Soil Conservation Service (1986), are in parentheses]

\begin{tabular}{|c|c|c|c|c|c|c|c|c|}
\hline \multirow[b]{2}{*}{ Major oxide } & \multicolumn{8}{|c|}{ Horizon } \\
\hline & $\mathrm{A} 1$ (A) & $A 2(E)$ & B21t $(B w)$ & B22tg (Bwg1) & $\mathrm{B} 23 \operatorname{tg}(\mathrm{Bwg} 2)$ & $\mathrm{B} 23 \operatorname{tg}(\mathrm{Btg} 1)$ & B24t (Btg2) & $2 \mathrm{C}$ \\
\hline $\mathrm{SiO}_{2} \ldots \ldots$ & 83.9 & 84.3 & 70.5 & 64.4 & 67.4 & 67.2 & 68.8 & 75.4 \\
\hline $\mathrm{Al}_{2} \mathrm{O}_{3}$ & 9.4 & 9.3 & 19.2 & 23.7 & 21.9 & 21.4 & 20.3 & 16.0 \\
\hline $\mathrm{Fe}_{2} \mathrm{O}_{3}$ & 1.3 & 1.3 & 4.1 & 5.4 & 4.2 & 4.9 & 4.5 & 2.5 \\
\hline $\mathrm{CaO}$ & .3 & .3 & .3 & .3 & .2 & .2 & .2 & .25 \\
\hline $\mathrm{K}_{2} \mathrm{O}$ & 2.7 & 2.7 & 2.1 & 1.7 & 1.9 & 1.9 & 2.0 & 2.2 \\
\hline $\mathrm{TiO}_{2}$ & 1.6 & 1.7 & 1.3 & 1.2 & 1.3 & 1.2 & 1.2 & 1.4 \\
\hline $\mathrm{MnO}$ & .1 & .06 & .03 & .02 & .03 & .03 & .03 & .04 \\
\hline $\mathrm{Fe}_{2} \mathrm{O}_{3} / \mathrm{Al}_{2} \mathrm{O}_{3}$ & .14 & .14 & .21 & .23 & .19 & .23 & .22 & .16 \\
\hline
\end{tabular}


Table 4A. Field description of pedon S81AL-101-001

[The Tallapoosa River A soil is developed in Holocene-age fluvial sediments and was classified in the field as a fine silty siliceous, thermic Typic Hapludult. The study site is located at an altitude of $170 \mathrm{ft}(52 \mathrm{~m})$ above sea level in NW1/4, sec. 3, T. 16 N., R. 20 E.. Montgomery County. Alabatma. Mount Meigs 15-minute quadrangle. A radiocarbon date from this locality is $6,520 \mathrm{yr}$ B.P. on disseminated carbon exposed at the base of the alluvium along the Tallapoosa River, approximately $100 \mathrm{yd}(91 \mathrm{~m}$ ) from the study site (Markewich and Christopher, $1982 \mathrm{a}$ ). No entry, no data]

\begin{tabular}{|c|c|c|c|c|c|c|c|}
\hline $\begin{array}{l}\text { Depth } \\
(\mathrm{cm})\end{array}$ & Horizon $^{1}$ & $\begin{array}{l}\text { Moist } \\
\text { color }^{3}\end{array}$ & Texture 5 & Structure 6 & $\begin{array}{l}\text { Clay } \\
\text { skins }\end{array}$ & Roots & Boundary ${ }^{7}$ \\
\hline $0-22$ & $A p(A p)$ & $10 Y R 43$ & sil & $\operatorname{lmfgr}$ & & & $\mathrm{cW}$ \\
\hline $22-47$ & $\mathrm{~B} 21 \mathrm{t}^{2}(\mathrm{Bw})$ & $7.5 Y R 4.4$ & sic & $2 \mathrm{msbk}$ & & & \\
\hline $47-66$ & $\mathrm{~B} 2 \mathrm{It}^{2}(\mathrm{Bt})$ & 7.5 YR 44 & sic & $2 \mathrm{msbk}$ & & & $\mathrm{gw}$ \\
\hline $66-89$ & $\mathrm{~B} 22(\mathrm{Bt} 2)$ & $\begin{array}{l}\text { 10YR } 5: 6 \\
10 Y R 6 / 3^{4}, 10 Y R 2 / 1^{4}\end{array}$ & sic & $2 \mathrm{msbk}$ & & & $c w$ \\
\hline $89-123$. & $\mathrm{B} 2.3 \mathrm{t}^{2}(\mathrm{Bt} 3)$ & $\begin{array}{l}10 \text { YR } 5 / 8 \\
10 Y R 6 / 3^{4}, 10 Y R 2 / 1^{4}\end{array}$ & sicl & $2 \mathrm{msbk}$ & & & \\
\hline $123-161$ & $\mathrm{~B} 23 \mathrm{t}^{2}(\mathrm{Bt} 3)$ & $\begin{array}{l}\text { 10YR } 5 / 8 \\
10 Y R 6 / 3^{4}, 10 Y R 2 / 1^{4}\end{array}$ & sicl & $2 \mathrm{msbk}$ & & & $\mathrm{cw}$ \\
\hline $161-190$ &. $\mathrm{~B} 3(\mathrm{BC})$ & $7.5 Y R 4 / 4$ & 1 & lcsbk & & & as \\
\hline $190-215$ & $11 \mathrm{C}(\mathrm{C})$ & Brown and white & s & SG & & & \\
\hline
\end{tabular}

\footnotetext{
${ }_{2}^{1}$ New horizon designations, taken from Soil Conservation Service (1986), are given in parentheses.

${ }_{3}^{2}$ Horizon split for sampling.

3 Munsell notation.

${ }_{5}^{4}$ Mottles.

5 sil, silty loam; sic, silty clay; sicl, silty clay loam; l, loam; s, sand.

61, weak: 2, moderate; $f$, fine; m. medium; c, coarse; gr, granular; sbk, subangular blocky; SG, single grain.

cw, clear wavy; gw, gradual wavy; as, abrupt smooth.
}

Table 4B. Textural analysis of pedon S81AL-101-001

[Grain size in millimeters; all other values in weight percent. VF, very fine; F, fine; M, medium; C, coarse: VC. very coarse; , analyzed but below detectable limits; TR, trace]

\begin{tabular}{|c|c|c|c|c|c|c|c|c|c|c|c|c|}
\hline \multirow[b]{2}{*}{$\begin{array}{l}\text { Depth } \\
\text { (cm) }\end{array}$} & \multirow[b]{2}{*}{ Horizon $^{1}$} & \multicolumn{3}{|c|}{ Total } & \multirow[b]{2}{*}{ 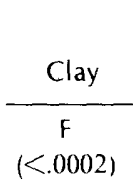 } & \multicolumn{2}{|c|}{ Silt } & \multicolumn{5}{|c|}{ Sand } \\
\hline & & $\begin{array}{l}\text { Clay } \\
(<.002)\end{array}$ & $\begin{array}{c}\text { Silt } \\
(.002- \\
.05)\end{array}$ & $\begin{array}{l}\text { Sand } \\
\text { (.05- } \\
2)\end{array}$ & & $\begin{array}{c}F \\
(.002- \\
.02)\end{array}$ & $\begin{array}{c}\mathrm{C} \\
(.02- \\
.05)\end{array}$ & $\begin{array}{l}\text { VF } \\
(.05- \\
.10)\end{array}$ & $\begin{array}{c}F \\
(.10- \\
.25)\end{array}$ & $\begin{array}{c}M \\
(.25- \\
.50)\end{array}$ & $\begin{array}{c}C \\
(.50- \\
1.0)\end{array}$ & $\begin{array}{l}V C \\
(1.0- \\
2.0)\end{array}$ \\
\hline $0-22 \ldots$ & $A p(A p)$ & 14.8 & 44.8 & 40.4 & 8.6 & 22.6 & 22.2 & 18.6 & 18.3 & 2.8 & 0.4 & 0.3 \\
\hline $22-47$. & $\mathrm{B} 21 \mathrm{t}(\mathrm{Bw})$ & 46.6 & 48.1 & 5.3 & 23.1 & 33.0 & 15.1 & 3.2 & 1.7 & .3 & .1 & TR \\
\hline $47-66$. & $\mathrm{B} 21 \mathrm{t}(\mathrm{Bt} 1)$ & 43.1 & 50.5 & 6.4 & 16.8 & 34.1 & 16.4 & 5.8 & .4 & .1 & .1 & -- \\
\hline $66-89 \ldots$ & $\mathrm{B} 22 \mathrm{t}(\mathrm{Bt} 2)$ & 40.2 & 52.1 & 7.7 & 16.8 & 36.1 & 16.0 & 7.0 & .6 & .1 & TR & TR \\
\hline $89-123 \ldots$ & $\mathrm{B} 23 \mathrm{t}(\mathrm{Bt} 3)$ & 25.3 & 50.1 & 24.6 & 8.2 & 24.5 & 25.6 & 22.9 & 1.5 & .1 & .1 & -- \\
\hline $123-161$. & $\mathrm{B} 23 \mathrm{t}(\mathrm{Bt} 3)$ & 26.4 & 44.4 & 29.2 & 9.4 & 25.2 & 19.2 & 20.2 & 8.6 & .2 & .1 & -- \\
\hline $161-190$. & $\mathrm{B} 3(\mathrm{BC})$ & 12.9 & 13.8 & 73.6 & 8.1 & 7.7 & 6.1 & 18.9 & 50.3 & 3.7 & .4 & -- \\
\hline $190-215$. & ..IIC (C) & 3.2 & 4.8 & 92.0 & .8 & 2.4 & 2.4 & 1.1 & 5.6 & 26.9 & 38.5 & 19.9 \\
\hline
\end{tabular}

\footnotetext{
${ }^{1}$ New horizon designations, taken from Soil Conservation Service (1986), are given in parentheses.
} 
Table 4C. Physical and chemical analyses of pedon S81AL-101-001

[Units of measure for all values given in table 1. . not detected; TR, trace]

\begin{tabular}{|c|c|c|c|c|c|c|c|c|c|c|}
\hline \multirow{3}{*}{$\begin{array}{l}\text { Depth } \\
(\mathrm{cm})\end{array}$} & \multirow[b]{3}{*}{ Horizon $^{1}$} & \multirow{3}{*}{$\underset{C}{\text { Organic }}$} & \multirow{3}{*}{$\begin{array}{l}\text { Total } \\
N\end{array}$} & \multicolumn{2}{|c|}{ Dithionite-citrate } & \multirow{2}{*}{\multicolumn{2}{|c|}{ Ratio clay }} & \multirow{2}{*}{\multicolumn{2}{|c|}{ Bulk density }} & \multirow[b]{3}{*}{$\mathrm{COLE}^{4}$} \\
\hline & & & & \multirow{2}{*}{$\begin{array}{c}\text { Extractable } \\
\mathrm{Fe}\end{array}$} & \multirow{2}{*}{$\begin{array}{c}\text { Extractable } \\
\text { Al }\end{array}$} & & & & & \\
\hline & & & & & & $\mathrm{CEC}^{2}$ & 15 bar $^{3}$ & $1 / 3 \mathrm{bar}$ & Oven dry & \\
\hline $0-22 \ldots \ldots$ & Ap $(A p)$ & 1.13 & 0.081 & 0.9 & 0.1 & 0.50 & 0.45 & 1.43 & 1.45 & 0.005 \\
\hline $22-47 \ldots$ & $\mathrm{B} 21 \mathrm{t}(\mathrm{Bw})$ & .41 & .045 & 2.2 & .2 & .37 & .38 & 1.45 & 1.60 & .033 \\
\hline $47-66 \ldots$ & $\mathrm{B} 2 \mathrm{lt}(\mathrm{Bt} 1)$ & .34 & .033 & 2.5 & .3 & .38 & .39 & 1.50 & - - & - \\
\hline $66-89 \ldots$ & $\mathrm{B} 22 \mathrm{t}(\mathrm{Bt} 2)$ & .35 & .046 & 2.4 & .3 & .36 & .40 & 1.56 & 1.65 & .019 \\
\hline $89-123 \ldots$ & $\mathrm{B} 23 \mathrm{t}(\mathrm{Bt} 3)$ & .25 & -- & 1.9 & .2 & .36 & .45 & 1.60 & -- & - \\
\hline $123-161$ & $\mathrm{~B} 23 \mathrm{t}(\mathrm{Bt} 3)$ & .23 & -- & 1.9 & .2 & .39 & .43 & 1.56 & 1.61 & .011 \\
\hline $161-190$ & $\mathrm{~B} 3(\mathrm{BC})$ & .20 & -- & 1.0 & .1 & .36 & .41 & 1.60 & -- & -- \\
\hline $190-215$ & $.11 \mathrm{C}(\mathrm{C})$ & .22 & - & .3 & TR & .44 & .56 & 1.60 & - & - \\
\hline
\end{tabular}

\begin{tabular}{|c|c|c|c|c|c|c|c|c|c|c|c|}
\hline \multirow{3}{*}{$\begin{array}{c}\text { Depth } \\
\text { (cm) }\end{array}$} & \multirow[b]{3}{*}{ Horizon $^{1}$} & \multirow{2}{*}{\multicolumn{2}{|c|}{ Water content }} & \multirow[b]{3}{*}{ WRD 5} & \multicolumn{5}{|c|}{$\mathrm{NH}_{4} \mathrm{OAC}$ extractable bases } & \multirow[b]{3}{*}{ Acidity } & \multirow{3}{*}{$\begin{array}{c}\text { Extractable } \\
\mathrm{Al}\end{array}$} \\
\hline & & & & & \multirow[b]{2}{*}{$\mathrm{Ca}$} & \multirow[b]{2}{*}{$\mathrm{Mg}$} & \multirow[b]{2}{*}{$\mathrm{Na}$} & \multirow[b]{2}{*}{ K } & \multirow{2}{*}{$\begin{array}{c}\text { Sum of } \\
\text { bases }\end{array}$} & & \\
\hline & & $1 / 3 \mathrm{bar}$ & 15 bar $^{3}$ & & & & & & & & \\
\hline $22-47$ & $\mathrm{~B} 2 \mathrm{lt}(\mathrm{Bw})$ & 26.3 & 17.6 & .13 & 4.1 & 2.4 & 0.1 & .1 & 6.7 & 11.4 & 2.1 \\
\hline $47-66$ & $\mathrm{~B} 21 \mathrm{t}(\mathrm{Btl})$ & - & 16.9 & & 1.8 & 1.8 & .1 & .1 & 3.8 & 12.6 & 3.8 \\
\hline $66-89$. & $\mathrm{B} 22 \mathrm{t}(\mathrm{Bt} 2)$ & 25.5 & 16.0 & .15 & 1.1 & 1.6 & .1 & .1 & 2.9 & 11.8 & 3.8 \\
\hline $162-190$ & $\mathrm{~B} 3(\mathrm{BC})$ & & 5.3 & -- & .4 & .7 & .1 & .1 & 1.3 & 4.8 & 1.7 \\
\hline $190-215$ & $\| 11 C(C)$ & - & 1.8 & -- & .3 & .2 & - & TR & .5 & 1.4 & .2 \\
\hline
\end{tabular}

\begin{tabular}{|c|c|c|c|c|c|c|c|c|c|c|}
\hline \multirow{3}{*}{$\begin{array}{l}\text { Depth } \\
\text { (cm) }\end{array}$} & \multirow[b]{3}{*}{ Horizon ${ }^{1}$} & \multicolumn{3}{|c|}{$\mathrm{CEC}^{2}$} & \multirow{3}{*}{$\underset{\text { saturation }}{\mathrm{Al}}$} & & & \multicolumn{3}{|c|}{$\mathrm{pH}$} \\
\hline & & \multirow{2}{*}{$\begin{array}{l}\text { Sum of } \\
\text { cations }\end{array}$} & \multirow[b]{2}{*}{$\mathrm{NH}_{4} \mathrm{OAC}$} & \multirow{2}{*}{$\begin{array}{c}\text { Bases + } \\
\text { Al }\end{array}$} & & \multicolumn{2}{|c|}{ Base saturation } & \multirow[b]{2}{*}{$\mathrm{KCl}$} & \multirow{2}{*}{$\begin{array}{l}\mathrm{CaCl}_{2} \\
(1: 2)\end{array}$} & \multirow{2}{*}{$\begin{array}{l}\mathrm{H}_{2} \mathrm{O} \\
(1: 1)\end{array}$} \\
\hline & & & & & & Sum & $\mathrm{NH}_{4} \mathrm{OAC}$ & & & \\
\hline $0-22$. & $A p(A p)$ & 10.6 & 7.4 & 3.7 & 5 & 33 & 47 & 4.3 & 5.3 & 5.5 \\
\hline $22-47$ & $\mathrm{~B} 21 \mathrm{t}(\mathrm{Bw})$ & 18.1 & 17.4 & 8.8 & 24 & 37 & 39 & 3.5 & 4.8 & 5.2 \\
\hline $47-66$ & $\mathrm{~B} 21 \mathrm{t}(\mathrm{Bt1})$ & 16.4 & 16.2 & 7.6 & 50 & 23 & 23 & 3.3 & 4.7 & 5.1 \\
\hline $66-89 \ldots$ & $\mathrm{B} 22 \mathrm{t}(\mathrm{Bt} 2)$ & 14.7 & 14.5 & 6.7 & 57 & 20 & 20 & 3.3 & 4.7 & 5.1 \\
\hline $89-123 \ldots$ & $\mathrm{B} 27(\mathrm{Bt} 3)$ & 10.9 & 9.2 & 5.2 & 56 & 21 & 25 & 3.4 & 4.7 & 5.1 \\
\hline $123-161$ & $\mathrm{~B} 23 \mathrm{t}(\mathrm{Bt} 3)$ & 11.5 & 10.3 & 5.4 & 59 & 19 & 21 & 3.3 & 4.6 & 5.0 \\
\hline $161-190$ & $\mathrm{~B} 3(\mathrm{BC})$ & 6.1 & 4.7 & 3.0 & 57 & 21 & 28 & 3.5 & 4.4 & 5.0 \\
\hline $190-215$ & $.11 \mathrm{C}(\mathrm{C})$ & 1.9 & 1.4 & .7 & 29 & 26 & 36 & 4.0 & 4.5 & 5.1 \\
\hline
\end{tabular}

\footnotetext{
INew horizon designations, taken from Soil Conservation Service (1986), are given in parentheses.

2 Cation exchange capacity.

${ }^{3}$ Water content at 15 -bar pressure.

${ }^{4}$ Coefficient of linear extensibility.

${ }^{5}$ Water-retention difference.
} 
Table 4D. Optical mineralogy of very fine sand fraction of selected horizons of pedon S81AL-101-001

[Muscovite is the dominant weatherable mineral in all horizons for count; potassium feldspar is dominant for adjusted count. TR, trace]

Mineral $\quad \begin{gathered}\text { Count } \\ \text { (percent) }\end{gathered} \quad \begin{gathered}\text { Adjusted count } \\ \text { (percent) }\end{gathered}$

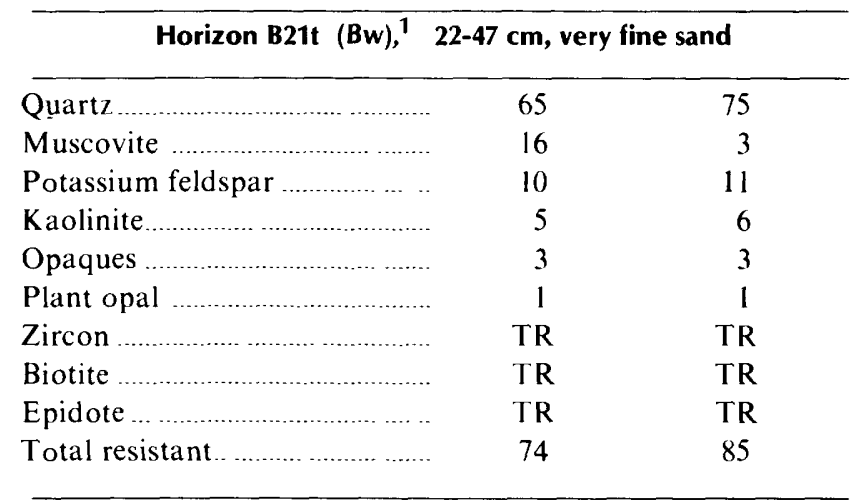

\begin{tabular}{|c|c|c|}
\hline \multicolumn{3}{|c|}{ Horizon B23t (Bt3), ${ }^{1} 123-161 \mathrm{~cm}$, very fine sand } \\
\hline Quartz ........... & 62 & 78 \\
\hline Muscovite & 21 & 1 \\
\hline Potassium feldspar ......................... & 8 & 10 \\
\hline Biotite & 4 & 1 \\
\hline Opaques & 2 & 3 \\
\hline Epidote & 1 & 2 \\
\hline Kaolinite................... & 1 & 1 \\
\hline Zircon & TR & TR \\
\hline Rutile & $\mathrm{TR}$ & TR \\
\hline Plant opal & TR & TR \\
\hline Hornblende & TR & TR \\
\hline Total resistant & 65 & 82 \\
\hline
\end{tabular}

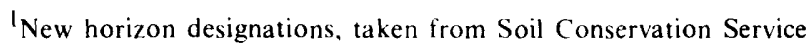
(1986), are in parentheses.
}

Table 4E. Bulk chemistry of pedon S81AL-101-001

[All values in weight percent except for $\mathrm{Fe}_{2} \mathrm{O}_{3} / \mathrm{Al}_{2} \mathrm{O}_{3}$, which is a ratio. New horizon designations, taken from Soil Conservation Service (1986), are in parentheses]

\begin{tabular}{|c|c|c|c|c|c|c|c|c|}
\hline \multirow[b]{2}{*}{ Major oxide } & \multicolumn{8}{|c|}{ Horizon } \\
\hline & $A P(A p)$ & $\mathrm{B} 21 \mathrm{t}(\mathrm{Bw})$ & $\mathrm{B} 21 \mathrm{t}(\mathrm{Bt} 1)$ & $\mathrm{B} 22 \mathrm{t}(\mathrm{B}+2)$ & $\mathrm{B} 23 \mathrm{t}(\mathrm{B}+3)$ & $\mathrm{B} 23 \mathrm{t}(\mathrm{Bt} 3)$ & B3 (BC) & $2 C(C)$ \\
\hline $\mathrm{SiO}_{2} \ldots \ldots \ldots$ & 78.2 & 65.0 & 64.8 & 62.0 & 68.7 & 66.1 & 65.2 & 70.3 \\
\hline $\mathrm{Al}_{2}{ }_{2} \mathrm{O}_{3}$ & 12.5 & 21.9 & 22.81 & 22.9 & 19.1 & 20.6 & 20.0 & 17.9 \\
\hline $\mathrm{Fe}_{2} \mathrm{O}_{3}$ & 3.8 & 6.6 & 7.3 & 6.8 & 6.4 & 6.9 & 7.4 & 6.0 \\
\hline $\mathrm{CaO}$ & 0.6 & .4 & .4 & .4 & .5 & .4 & 6 & .5 \\
\hline $\mathrm{K}_{2} \mathrm{O}$ & 2.1 & 2.4 & 2.5 & 2.4 & 2.2 & 2.4 & 2.2 & 2.3 \\
\hline $\mathrm{TiO}_{2}$ & 1.6 & 1.3 & 1.3 & 1.3 & 1.6 & 1.5 & 1.7 & 1.6 \\
\hline $\mathrm{MnO}$ & 0.4 & .1 & .08 & .1 & .1 & .1 & .2 & .2 \\
\hline $\mathrm{Fe}_{2} \mathrm{O}_{3} / \mathrm{Al}_{2} \mathrm{O}_{3}$ & .30 & .30 & .32 & .30 & .34 & .34 & .37 & .34 \\
\hline
\end{tabular}


Table 5A. Field description of pedon S81AL-101-002

[The Tallapoosa River B soil is developed in Holocene-age alluvium dated at 5.500 yr B.P. (Markewich and Christopher, 1982a). The series is not designated; the soil was tentatively classified on the basis of field evidence as a fine silty, mixed thermic Typic Dystrochrept. The study site is located in SW $1 \frac{1}{4}$. sec. 26, T. 17 N.. R. 19 E., Montgomery County, Alabama, at an altitude of $155 \mathrm{ft}(47 \mathrm{~m})$ above sea level. Mount Meigs 15-minute quadrangle. No entry, no data]

\begin{tabular}{|c|c|c|c|c|c|c|c|}
\hline $\begin{array}{l}\text { Depth } \\
(\mathrm{cm})\end{array}$ & Horizon ${ }^{1}$ & $\begin{array}{l}\text { Moist } \\
\text { color }\end{array}$ & Texture $^{4}$ & Structure ${ }^{5}$ & $\begin{array}{l}\text { Clay } \\
\text { skins }\end{array}$ & Roots & Boundary 6 \\
\hline $0-8$ & $\mathrm{Al}(\mathrm{A})$ & $\begin{array}{l}\text { IOYR } 33 \\
\text { lOYR } 54^{3}, 7.5 \text { YR } 5.6^{3}\end{array}$ & sil & $\begin{array}{l}\text { lmsbk- } \\
\text { Imgr }\end{array}$ & & & $\mathrm{cs}$ \\
\hline $8-30 \ldots \ldots$ & $\mathrm{B} \mid(\mathrm{Bw} \mid)$ & $\begin{array}{l}7.5 \text { YR } 56 \\
10 Y R 2.1^{3}\end{array}$ & sicl & $2 \mathrm{csbk}$ & & & $\mathrm{cw}$ \\
\hline $30-54$ & $\mathrm{~B} 2 \mathrm{I}(\mathrm{B} \cup 2)$ & $\begin{array}{l}7.5 Y R 5,6 \\
10 Y R 2,1^{3}\end{array}$ & sicl & $2 \mathrm{msbk}$ & & & gs \\
\hline $54-94 \ldots$. & $\mathrm{B} 22(\mathrm{Bw} 3)$ & $\begin{array}{l}\text { 10YR } 5: 6 \\
10 Y R 2 \cdot 1^{3}, 10 Y R 6: 4^{3}\end{array}$ & sicl & $\begin{array}{l}2 \mathrm{mabk}- \\
2 \mathrm{msbk}\end{array}$ & & & gs \\
\hline $94-130$. & $B 23(B \cup 4)$ & $\begin{array}{l}7.5 \text { YR } 56 \\
10 \text { YR } 56^{3}, 10 \text { YR } 6: 2^{3}\end{array}$ & sicl & $\begin{array}{l}2 \mathrm{mabk}- \\
2 \mathrm{msbk}\end{array}$ & & & $\mathrm{cw}$ \\
\hline $130-164$ & $B 3(B C)$ & $\begin{array}{l}7.5 \text { YR } 5,6 \\
\text { 10YR } 5,6^{3}, 10 Y R 6 / 1^{3} \\
\text { 10YR } 6: 3^{3}, 10 Y R 2: 1^{3}\end{array}$ & sil & lcsbk & & & gw \\
\hline $164-190$ & $C(C)$ & $\begin{array}{l}10 \text { YR } 6 / 1^{3}, 10 \text { Y R } 5,6^{3} \\
7.5 \text { Y } 5,6^{3}, 10 \text { Y R } 3 / 3^{3}\end{array}$ & 1 & $\mathrm{~m}$ & & & \\
\hline
\end{tabular}

${ }_{2}^{1}$ New horizon designations; taken from Soil Conservation Service (1986), are given in parentheses.

2 Munsell notation.

${ }^{3}$ Mottles.

${ }_{5}^{4}$ sil. silt loam; sicl, silty clay loam; 1, loam.

5 I, weak; 2 , moderate; $m$, medium; c. coarse; sbk. subangular blocky; gr, granular; abk, angular blocky.

6 cs, clear smooth; cw, clear wavy: gs, gradual smooth; gw. gradual wavy.

Table 5B. Textural analysis of pedon S81AL-101-002

[Grain size in millimeters; all other values in weight percent. VF. very fine; F, fine; M, medium; C. coarse: VC, very coarse; TR, trace]

\begin{tabular}{|c|c|c|c|c|c|c|c|c|c|c|c|c|}
\hline \multirow[b]{2}{*}{$\begin{array}{l}\text { Depth } \\
\text { (cm) }\end{array}$} & \multirow[b]{2}{*}{ Horizon $^{1}$} & \multicolumn{3}{|c|}{ Total } & \multirow[b]{2}{*}{$\frac{\text { Clay }}{\underset{(<.0002)}{\mathbf{F}}}$} & \multicolumn{2}{|c|}{ Silt } & \multicolumn{5}{|c|}{ Sand } \\
\hline & & $\begin{array}{c}\text { Clay } \\
(<.002)\end{array}$ & $\begin{array}{l}\text { Silt } \\
(.002- \\
.05)\end{array}$ & $\begin{array}{l}\text { Sand } \\
\text { (.05- } \\
2)\end{array}$ & & $\begin{array}{c}F \\
(.002- \\
.02)\end{array}$ & $\begin{array}{c}\mathrm{C} \\
(.02- \\
.05)\end{array}$ & $\begin{array}{l}V F \\
(.05- \\
.10)\end{array}$ & $\begin{array}{c}F \\
(.70- \\
.25)\end{array}$ & $\begin{array}{c}M \\
(.25- \\
.50)\end{array}$ & $\begin{array}{c}C \\
(.50- \\
1.0)\end{array}$ & $\begin{array}{l}\text { VC } \\
(1.0- \\
2.0)\end{array}$ \\
\hline $0-8 \ldots \ldots$ & $\mathrm{Al}(\mathrm{A})$ & 20.7 & 41.4 & 37.9 & 8.4 & 26.4 & 15.0 & 22.1 & 13.5 & 1.3 & 0.5 & 0.1 \\
\hline $8-30 \ldots \ldots$ & $\mathrm{B} 1(\mathrm{Bw})$ & 38.1 & 50.4 & 11.5 & 17.0 & 33.1 & 17.3 & 8.2 & 2.9 & .3 & .1 & TR \\
\hline $30-54 \ldots$ & $\ldots \mathrm{B} 21(\mathrm{~B} w 2)$ & 37.1 & 48.7 & 14.2 & 16.9 & 30.9 & 17.8 & 10.7 & 3.2 & .2 & .1 & TR \\
\hline $54-94 \ldots$ & $\mathrm{B} 22(\mathrm{Bw} 3)$ & 33.8 & 54.8 & 11.4 & 13.2 & 33.8 & 21.0 & 9.6 & 1.6 & .2 & TR & TR \\
\hline $94-130 \ldots$ & B23 (Bw4) & 30.4 & 39.7 & 29.9 & 12.7 & 29.6 & 10.1 & 17.7 & 7.2 & 3.6 & .8 & .6 \\
\hline $130-164$. &. $\mathrm{B3}(\mathrm{BC})$ & 22.4 & 31.3 & 46.3 & 8.6 & 18.7 & 12.6 & 34.6 & 11.1 & .4 & .1 & .1 \\
\hline $164-190$. & $\ldots \mathrm{C}(\mathrm{C})$ & 18.3 & 38.9 & 42.8 & 10.6 & 17,5 & 21.4 & 26.4 & 15.4 & .9 & .1 & TR \\
\hline
\end{tabular}

\footnotetext{
${ }^{1}$ New horizon designations, taken from Soil Conservation Service (1986), are given in parentheses.
} 
Table 5C. Physical and chemical analyses of pedon S81AL-101-002

[Units of measure for all values given in table 1. -. not detected: TR, trace]

\begin{tabular}{|c|c|c|c|c|c|c|c|c|c|c|}
\hline \multirow{3}{*}{$\begin{array}{l}\text { Depth } \\
(\mathrm{cm})\end{array}$} & \multirow[b]{3}{*}{ Horizon ${ }^{1}$} & \multirow{3}{*}{$\underset{\mathrm{C}}{\text { Organic }}$} & \multirow{3}{*}{$\begin{array}{c}\text { Total } \\
N\end{array}$} & \multicolumn{2}{|c|}{ Dithionite-citrate } & \multirow{2}{*}{\multicolumn{2}{|c|}{ Ratio clay }} & \multirow{2}{*}{\multicolumn{2}{|c|}{ Bulk density }} & \multirow[b]{3}{*}{$\operatorname{COLE}^{4}$} \\
\hline & & & & \multirow{2}{*}{$\begin{array}{c}\text { Extractable } \\
\mathrm{Fe}\end{array}$} & \multirow{2}{*}{$\begin{array}{c}\text { Extractable } \\
\mathrm{Al}\end{array}$} & & & & & \\
\hline & & & & & & $\mathrm{CEC}^{2}$ & $15 \mathrm{bar}^{3}$ & $1 / 3 \mathrm{bar}$ & Oven dry & \\
\hline $0-8 \ldots \ldots \ldots$ & $\mathrm{A} 1(\mathrm{~A})$ & 3.77 & 0.208 & 1.3 & 0.2 & 0.77 & 0.60 & 1.40 & -- & -- \\
\hline $8-30 \ldots \ldots$ & $B I(B w I)$ & .61 & .055 & 2.1 & .3 & .35 & .42 & 1.41 & 1.64 & 0.028 \\
\hline $30-54$ & $\mathrm{~B} 21(\mathrm{Bw} 2)$ & .34 & .029 & 2.1 & .2 & .36 & .43 & 1.50 & -. & -- \\
\hline $54-94 \ldots$. & B22 (Bw3) & .32 & .039 & 2.1 & .2 & .40 & .46 & 1.44 & 1.56 & .027 \\
\hline $94-130 .$. &. $\mathrm{B} 23$ (Bw4) & .28 & - & 2.0 & .2 & .41 & .44 & 1.50 & -- & - \\
\hline $130-164$ & B3 (BC) & .22 & -- & 1.5 & .2 & .38 & .43 & 1.52 & 1.57 & .011 \\
\hline $164-190$ &.$C(C)$ & .22 & - & 1.4 & .2 & .45 & .49 & 1.50 & 1.54 & .011 \\
\hline
\end{tabular}

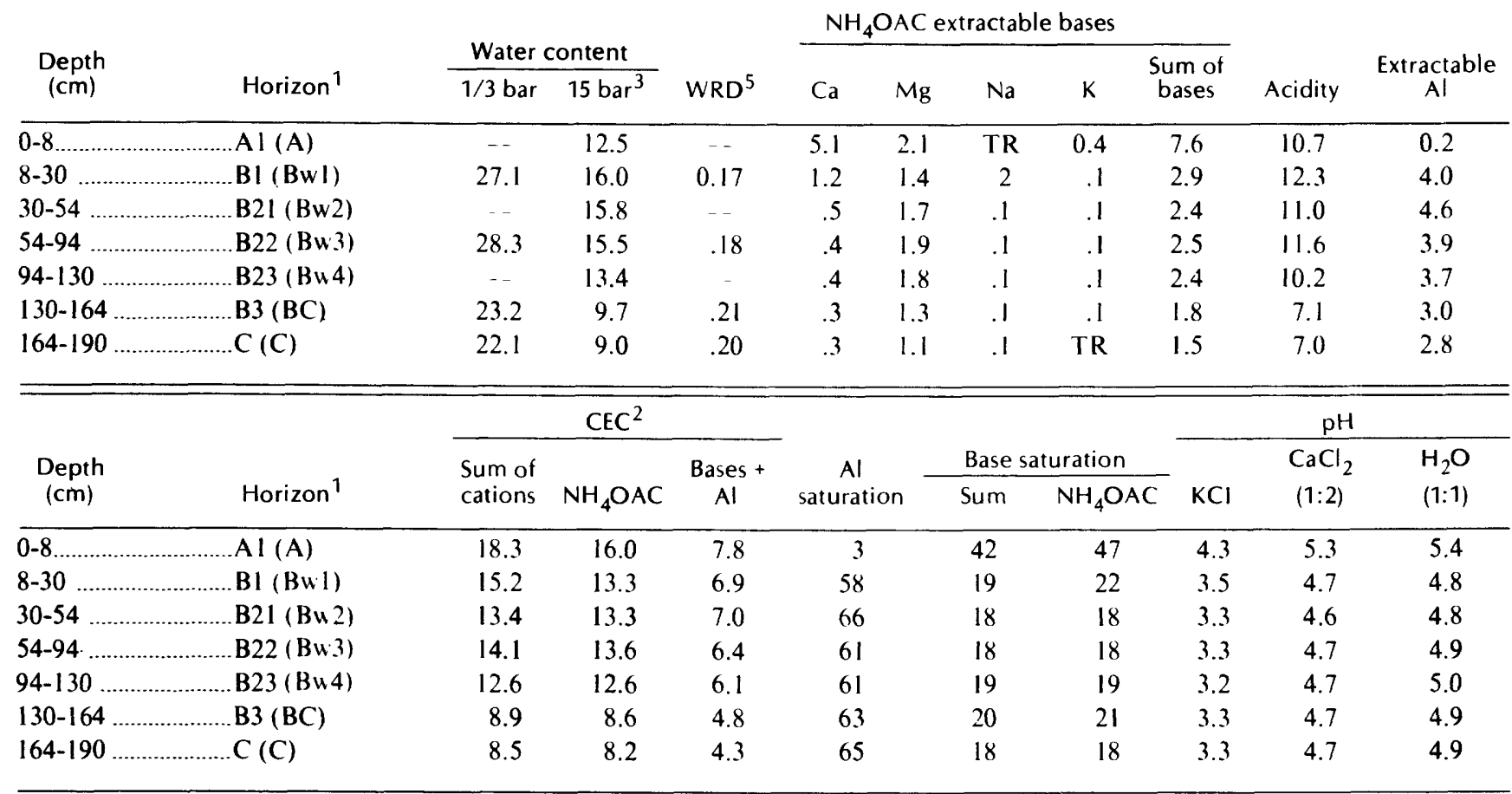

\footnotetext{
${ }^{1}$ New horizon designations, taken from Soil Conservation Service (1986), are given in parentheses.

${ }^{2}$ Cation exchange capacity.

${ }^{3}$ Water content at 15 -bar pressure.

${ }^{4}$ Coefficient of linear extensibility.

${ }^{5}$ Water-retention difference.
} 
Table 5D. Optical mineralogy of very fine sand fraction of selected horizons of pedon S81AL-101-002

[Muscovite is the dominant weatherable mineral in all horizons for count; potassium feldspar is dominant for adjusted count. TR, trace]

\begin{tabular}{|c|c|c|}
\hline Mineral & $\begin{array}{c}\text { Count } \\
\text { (percent) }\end{array}$ & $\begin{array}{l}\text { Adjusted count } \\
\text { (percent) }\end{array}$ \\
\hline \multicolumn{3}{|c|}{ Horizon B22 (Bw3), ${ }^{1} 54-94 \mathrm{~cm}$, very fine sand } \\
\hline Quartz & 57 & 73 \\
\hline Muscovite & 25 & 5 \\
\hline Potassium feldspar & 8 & 10 \\
\hline 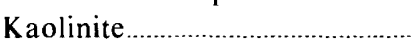 & 5 & 6 \\
\hline Opaques & 2 & 3 \\
\hline Epidote & 1 & 2 \\
\hline Plant opal & TR & TR \\
\hline Biotite & TR & TR \\
\hline Zircon & TR & TR \\
\hline 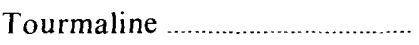 & TR & TR \\
\hline Hornblende & TR & TR \\
\hline Total resistant & 64 & 82 \\
\hline
\end{tabular}

\begin{tabular}{|c|c|c|}
\hline \multicolumn{3}{|c|}{ Horizon $C(C),{ }^{1} 164-190 \mathrm{~cm}$, very fine sand } \\
\hline Quartz .......... & 65 & 77 \\
\hline 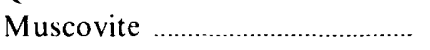 & 16 & 3 \\
\hline Potassium feldspar... & 9 & 11 \\
\hline Epidote & 3 & 3 \\
\hline 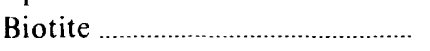 & 2 & TR \\
\hline Kaolinite & 2 & 3 \\
\hline Opaques & 2 & 2 \\
\hline Hornblende & 1 & 1 \\
\hline Zircon & TR & TR \\
\hline Total resistant & 69 & 82 \\
\hline
\end{tabular}

\footnotetext{
${ }^{1}$ New horizon designations, taken from Soil Conservation Service (1986), are in parentheses.
}

Table 5E. Bulk chemistry of pedon S81AL-101-002

[All values in weight percent except for $\mathrm{Fe}_{2} \mathrm{O}_{3} / \mathrm{Al}_{2} \mathrm{O}_{3}$, which is a ratio. New horizon designations, taken from Soil Conservation Service (1986), are in parentheses]

\begin{tabular}{|c|c|c|c|c|c|c|c|}
\hline \multirow[b]{2}{*}{ Major oxide } & \multicolumn{7}{|c|}{ Horizon } \\
\hline & $\mathrm{A} 1$ (A) & $\mathrm{B1}(\mathrm{Bw} 1)$ & $\mathrm{B} 21(\mathrm{Bw} 2)$ & $\mathrm{B} 22(\mathrm{Bw} 3)$ & B23 (Bw4) & $\mathrm{B} 3(\mathrm{BC})$ & $C(C)$ \\
\hline $\mathrm{SiO}_{2} \ldots \ldots$ & 71.1 & 64.3 & 65.7 & 65.4 & 70.3 & 69.8 & 72.4 \\
\hline $\mathrm{Al}_{2} \mathrm{O}_{3}$ & 17.6 & 21.7 & 21.8 & 21.5 & 13.9 & 14.5 & 14.0 \\
\hline $\mathrm{Fe}_{2} \mathrm{O}_{3}$ & 5.4 & 6.0 & 6.5 & 6.7 & 4.5 & 4.5 & 4.2 \\
\hline $\mathrm{CaO} \ldots$ & .6 & .4 & .4 & .3 & .2 & .4 & .4 \\
\hline $\mathrm{K}_{2} \mathrm{O}$ & 2.3 & 2.3 & 2.4 & 2.5 & 1.8 & 1.9 & 2.0 \\
\hline TiO & 1.6 & 1.3 & 1.4 & 1.4 & 1.0 & 1.1 & 1.1 \\
\hline $\mathrm{MnO}$ & .2 & .2 & .1 & .1 & .1 & .09 & .09 \\
\hline $\mathrm{Fe}_{2} \mathrm{O}_{3} / \mathrm{Al}_{2} \mathrm{O}_{3}$ & .31 & .28 & .30 & .31 & .32 & .31 & .30 \\
\hline
\end{tabular}


Table 6. Intervals of maximum clay accumulation versus intervals of translocated clay

\begin{tabular}{|c|c|c|}
\hline Pedon & $\begin{array}{l}\text { Macroscopic evidence for } \\
\text { clay maxima in } \\
\text { fining-upward sequence }\end{array}$ & $\begin{array}{l}\text { Microscopic evidence } \\
\text { for clay cutans }\end{array}$ \\
\hline S81AL-087-001 & $\begin{array}{l}\text { Fining-upward sequence } \\
\text { between } 73 \text { and } 200 \mathrm{~cm} \\
\text { (see table } 2 \mathrm{~B} \text { ). }\end{array}$ & None. \\
\hline S81 AL-087-002 & $\begin{array}{l}\text { Fining-upward sequence } \\
\text { between } 58 \text { and } 176 \mathrm{~cm} \\
\text { (see table } 3 B \text { ). }\end{array}$ & $\begin{array}{l}\text { Slight }(36-58 \mathrm{~cm}) \\
\text { Slight }(78-176 \mathrm{~cm})\end{array}$ \\
\hline S8IAL-I01-001 ................................ & $\begin{array}{l}\text { Fining-upward sequence } \\
\text { between } 22 \text { and } 213 \mathrm{~cm} \\
\text { (see table } 4 B \text { ). }\end{array}$ & Definite $(47-161 \mathrm{~cm})$ \\
\hline S81 AL-101-002 & $\begin{array}{l}\text { Fining-upward sequence } \\
\text { between } 8 \text { and } 190 \mathrm{~cm} \\
\text { (see table } 5 B \text { ). }\end{array}$ & $\begin{array}{l}\text { Distinct }(0-8 \mathrm{~cm}) . \\
\text { Definite }(30-130 \mathrm{~cm}) . \\
\text { Distinct }(130-164 \mathrm{~cm}) .\end{array}$ \\
\hline
\end{tabular}

Table 7. Particle-size distribution of sand on clay-free base for each pedon

[VF, very fine: F. fine; $M$, medium: C. coarse: VC, very coarse; no entry. no data]

\begin{tabular}{|c|c|c|c|c|c|}
\hline \multirow{2}{*}{$\begin{array}{l}\text { Depth } \\
(\mathrm{cm})\end{array}$} & \multicolumn{5}{|c|}{ Sand } \\
\hline & $V F$ & $\mathrm{~F}$ & $M$ & $\mathrm{C}$ & VC \\
\hline \multicolumn{6}{|c|}{ S81AL-087-001 } \\
\hline $0-26 \ldots \ldots \ldots \ldots$ & 53.6 & 17.3 & 1.8 & & \\
\hline $26-47 \ldots \ldots \ldots \ldots$ & 52.8 & 19.7 & 2.2 & & \\
\hline $47-73 \ldots \ldots \ldots \ldots \ldots$ & 50.3 & 27.3 & 2.3 & & \\
\hline $73-97 \ldots \ldots \ldots \ldots$ & 40.9 & 9.1 & 4.2 & & \\
\hline $97-115 \ldots \ldots \ldots$ & 40.4 & 11.4 & 1.8 & & \\
\hline $115-130 \ldots \ldots$ & 40.6 & 31.0 & 1.9 & & \\
\hline $130-170 \ldots$ & 46.8 & 31.0 & 11.5 & & \\
\hline $170-200$ & 13.4 & 31.7 & 33.8 & & \\
\hline \multicolumn{6}{|c|}{ S81AL-087-002 } \\
\hline $0-20 \ldots$ & 29.0 & 20.8 & 8.5 & 8.8 & 4.0 \\
\hline $20-36$. & 31.8 & 21.3 & 8.4 & 6.6 & 3.2 \\
\hline $36-58 \ldots \ldots \ldots \ldots \ldots \ldots \ldots$ & 28.6 & 17.7 & 8.6 & 5.6 & 1.9 \\
\hline $58-78 \ldots \ldots \ldots \ldots$ & 21.0 & 16.8 & 12.2 & 7.2 & 2.2 \\
\hline $78-112 \ldots \ldots \ldots$ & 24.0 & 19.3 & 12.5 & 7.4 & 2.7 \\
\hline $112-146 \ldots \ldots \ldots$ & 23.9 & 22.2 & 17.4 & 7.4 & 1.2 \\
\hline $146-176 \ldots \ldots$ & 25.1 & 23.6 & 17.9 & 9.0 & 3.0 \\
\hline \multicolumn{6}{|c|}{ S81AL-101-001 } \\
\hline $0-22 \ldots \ldots \ldots \ldots \ldots$ & 21.8 & 21.5 & 3.3 & & \\
\hline $22-47 \ldots \ldots \ldots$ & 6.0 & 3.2 & & & \\
\hline $47-66 \ldots \ldots \ldots \ldots$ & 10.2 & .7 & & & \\
\hline $66-89 \ldots \ldots \ldots \ldots \ldots$ & 11.7 & 1.0 & & & \\
\hline $89-123 \ldots \ldots \ldots \ldots$ & 30.7 & 2.0 & & & \\
\hline $123-161 \ldots$ & 27.4 & 11.7 & & & \\
\hline $161-190 \ldots \ldots \ldots \ldots$ & 21.6 & 57.6 & 4.2 & & \\
\hline $190-215 \ldots \ldots \ldots$ & 1.1 & 5.8 & 27.8 & 39.8 & 20.6 \\
\hline \multicolumn{6}{|c|}{ S81AL-101-002 } \\
\hline $0-8 \ldots$ & 27.9 & 17.0 & & & \\
\hline $8-30 \ldots \ldots \ldots \ldots$ & 13.3 & 4.7 & & & \\
\hline $30-54 \ldots \ldots \ldots \ldots$ & 17.0 & 5.1 & & & \\
\hline $54-94 \ldots \ldots \ldots \ldots \ldots$ & 14.5 & 2.4 & & & \\
\hline $94-130 \ldots \ldots \ldots \ldots$ & 25.4 & 10.3 & 5.2 & & \\
\hline $130-164 \ldots \ldots \ldots \ldots$ & 44.6 & 14.3 & & & \\
\hline $164-190 \ldots$ & 32.3 & 18.9 & & & \\
\hline
\end{tabular}




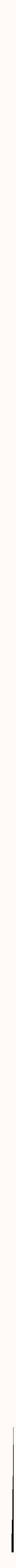




\section{Perlodicals}

Earthquakes \& Volcanoes (issued bimonthly).

Prellminary Determination of Eplcenters (issued monthly).

\section{Technical Books and Reports}

Professional Papers are mainly comprehensive scientific reports of wide and lasting interest and importance to professional scientists and engineers. Included are reports on the results of resource studies and of topographic, hydrologic, and geologic investigations. They also include collections of related papers addressing different aspects of a single scientific topic.

Bulletins contain significant data and interpretations that are of lasting scientific interest but are generally more limited in scope or geographic coverage than Professional Papers. They include the results of resource studies and of geologic and topographic investigations; as well as collections of short papers related to a specific topic.

Water-Supply Papers are comprehensive reports that present significant interpretive results of hydrologic investigations of wide interest to professional geologists, hydrologists, and engineers. The series covers investigations in all phases of hydrology, including hydrogeology, availability of water, quality of water, and use of water.

Circulars present administrative information or important scientific information of wide popular interest in a format designed for distribution at no cost to the public. Information is usually of short-term interest.

Water-Resources Investigations Reports are papers of an interpretive nature made available to the public outside the formal USGS publications series. Copies are reprociuced on request unlike formal USGS publications, and they are also available for public inspection at depositories indicated in USGS catalogs.

Open-File Reports include unpublished manuscript reports, maps, and other material that are made available for public consultation at depositories. They are a nonpermanent form of publication that may be cited in other publications as sources of information.

\section{Maps}

Geologic Quadrangle Maps are multicolor geologic maps on topographic bases in 7 1/2-or 15-minute quadrangle formats (scales mainly $1: 24,000$ or $1: 62,500$ ) showing bedrock, surficial, or engineering geology. Maps generally include brief texts; some maps include structure and columnar sections only.

Geophysical Investigations Maps are on topographic or planimetric bases at various scales; they show results of surveys using geophysical techniques, such as gravity, magnetic, seismic, or radioactivity, which reflect subsurface structures that are of economic or geologic significance. Many maps include correlations with the geology.

Misceilaneous Investigations Series Maps are on planimetric or topographic bases of regular and irregular areas at various scales; they present a wide variety of format and subject matter. The series also includes 7 1/2-minute quadrangle photogeologic maps on planimetric bases which show geology as interpreted from aerial photographs. Series also includes maps of Mars and the Moon.
Coal Investigations Maps are geologic maps on topographic ot planimetric bases at various scales showing bedrock or surficial geol. ogy, stratigraphy, and structural relations in certain coal-resource areas.

Oll and Gas Investigations Charts show stratigraphic information for certain oil and gas fields and other areas having petroleum potential.

Miscellaneous Field Studies Maps are multicolor or black-andwhite maps on topographic or planimetric bases on quadrangle or irregular areas at various scales. Pre-1971 maps show bedrock geology in relation to specific mining or mineral-deposit problems; post-1971 maps are primarily black-and-white maps on various subjects such as environmental studies or wildemess mineral investigations.

Hydrologic Investigations Atlases are multicolored or black-andwhite maps on topographic or planimetric bases presenting a wide range of geohydrologic data of both regular and irregular areas; principal scale is $1: 24,000$ and regional studies are at $1: 250,000$ scale or smaller.

\section{Catalogs}

Permanent catalogs, as well as some others, giving comprehensive listings of U.S. Geological Survey publications are available undethe conditions indicated below from the U.S. Geological Survey, Books and Open-File Reports Section, Federal Center, Box 25425, Denver CO 80225. (See latest Price and Availability List.)

"Publications of the Geological Survey, 1879-1961" may be purchased by mail and over the counter in paperback book form and as a set of microfiche.

"Publications of the Geological Survey, 1962-1970" may be purchased by mail and over the counter in paperback book form and as set of microfiche.

"Publications of the U.S. Geological Survey, 1971- 1981" may be purchased by mail and over the counter in paperback book form (two volumes, publications listing and index) and as a set of microfiche.

Supplements for 1982, 1983, 1984, 1985, 1986, and for subsequent years since the last permanent catalog may be purchased by mail and over the counter in paperback book form.

State catalogs, "List of U.S. Geological Survey Geologic and Water-Supply Reports and Maps For (State)," may be purchased by mail and over the counter in paperback booklet form only.

"Price and Availability List of U.S. Geological Survey Publica tions," issued annually, is available free of charge in paperback book let form only.

Selected copies of a monthly cataiog "New Publications of the U.S. Geological Survey" available free of charge by mail or may be obtained over the counter in paperback booklet form only. Those wishing a free subscription to the monthly catalog "New Publications of the U.S. Geological Survey" should write to the U.S. Geological Survey. 582 National Center, Reston, VA 22092.

Note.--Prices of Government publications listed in older catalogs, announcements, and publications may be incorrect. Therefore, the prices charged may differ from the prices in catalogs, announcements, and publications. 


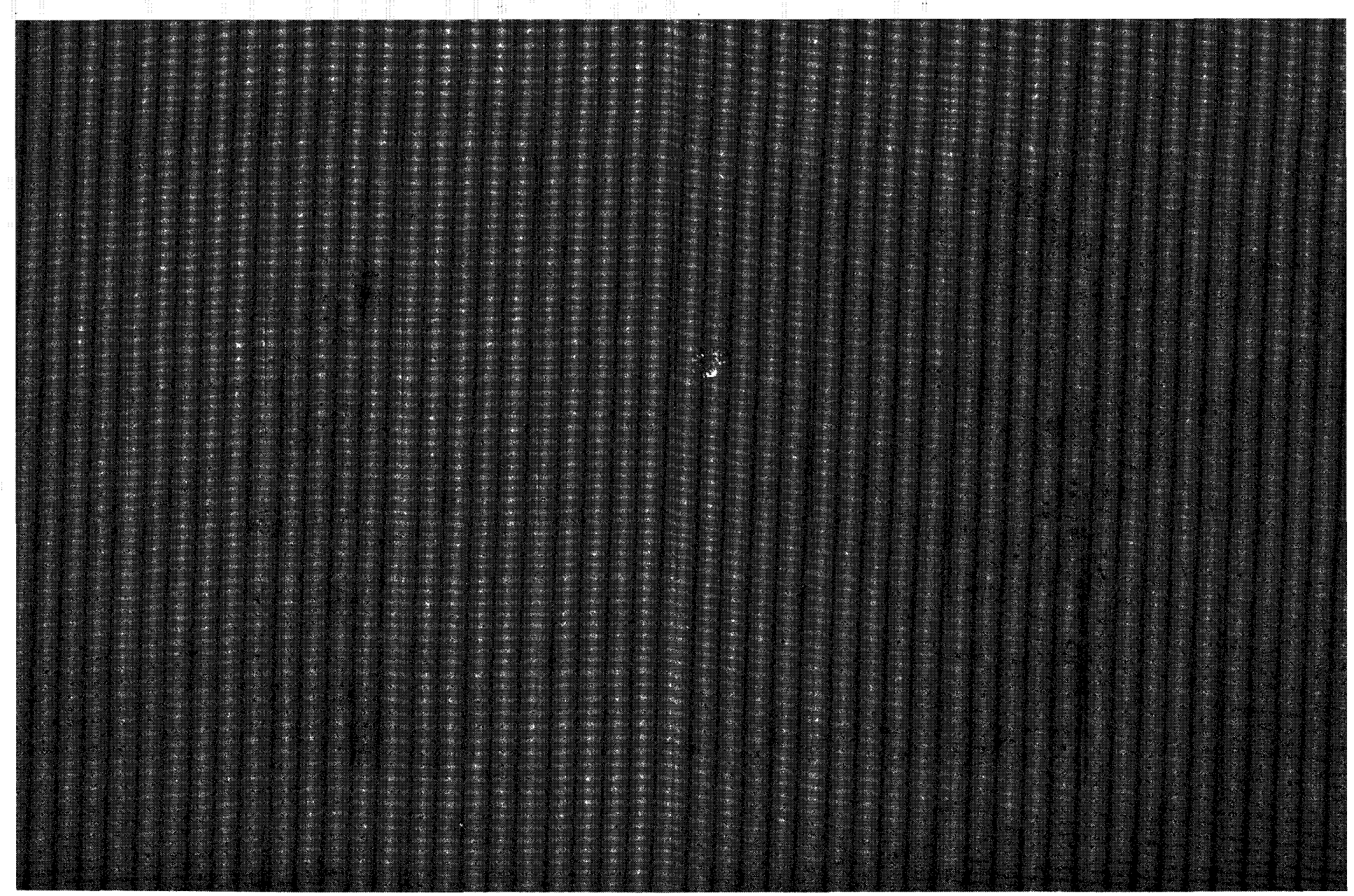

